The Relationship between Earnings Benchmarks and Earnings Management .....

Dr/ Amr Nazieh Mahmoud Ezat

\title{
The Relationship between Earnings Benchmarks and Earnings Management across the Stages of a Listed Egyptian Firm's Life Cycle
}

Amr Nazieh Mahmoud Ezat

Associate Professor, Accounting Department, Faculty of

Commerce, Mansoura University

\section{Abstract}

Firms have different stages in their life that have various characteristics and required different strategies. Therefore, firms may apply different tools of earnings management techniques to achieve specific earnings benchmarks through their life cycle. The purpose of the current study is to examine relationship between the firm's life cycle, earnings management and earnings benchmarks in the Egyptian environment. By using a sample of non-financial Egyptian listed firms from 2016 to 2019, the study constructs ten models of panel data regression analysis to test the hypotheses. The descriptive results indicates that most of the Egyptian firms are in the decline stages and achieve various earnings benchmarks across the various stages of life cycle. Further, Egyptian firms apply more than on tools of earnings management for all stages of their life cycle. The empirical findings illustrate that each stage of the life cycle for Egyptian firms has an impact on the earnings attributes and all stages except mature stage- are engaged in earnings management tools. 
The Relationship between Earnings Benchmarks and Earnings Management .....

Dr/ Amr Nazieh Mahmoud Ezat

In addition, the findings provide evidence for the impact of earnings management tools on earning benchmarks across the various stages of Egyptian firm life cycle. The paper contributes to the literature through considering the interrelated relationship between firm's life cycle, earnings management tools, and earnings benchmarks which not examined widely in prior studies.

\section{Key words:}

Firm Life cycle, Earnings management, Earnings benchmarks.

\section{Introduction}

When examining the Meeting or Beating of Earnings (MBE), previous studies concentrated mainly on capital market incentives (Kasznik and McNicchols, 2002; Brown and Caylor 2005; Graham et al., 2005), top management compensation (Matsunaga and Park, 2001; Cheng and Warfield, 2005; Bauman et al., 2005), the effect on the cost of debt capital (Jiang, 2008), the motivation of MBE (McVay et al., 2006), its mechanisms (Ayers et al. 2006), and its association with earnings management (Roychowdhury, 2006; Habib and Hansen, 2008; Siriviriyakul, 2014). However, few studies investigated the impact of firm's life cycle stages on MBE. One of this study's main objectives is to examine such a relationship. More specifically, the study investigates the incentives for the sampled Egyptian firms to either meet or beat their earnings benchmarks across the various stages of their life cycles.

Firm's life cycle theory assumes that the firm's development 
The Relationship between Earnings Benchmarks and Earnings Management .....

Dr/ Amr Nazieh Mahmoud Ezat

occurs across the different stages of its life cycle. These are characterized by different financial attributes, the different strategies and the requirement of various management skills (Hansen et al., 2018). Consequently, a firm's life cycle refers to the stages that reflect its evolution over its life (Miller and Friesen 1984; Choi et al., 2016). Accordingly, each stage of the firm's life cycle has its unique characteristics which require different strategies (Jenkins et al., 2004; Kallunki and Silvola, 2008; Dickinson 2011).

Firms follow conservative strategies depending on the earnings information detailed in their financial statements (Graham et al., 2005). Since firms may differ in their strategies according to the stages of their life cycles, this study posits that each stage of a firm's life cycle may influence its earnings benchmark.

In addition, many previous researchers have been attracted by the different aspects of earnings management. Most of the previous literature investigated the manipulation of the accounting information through different tools of earnings management such as accruals, real earnings management, and classification shifting. However, few studies have examined the influence of the firm's life cycle on earnings management tools. Therefore, this study sheds light on the possible relationship between earnings management and the firm's life cycle. Consequently, this study's second objective is to examine the possible relationship between the application of earnings 
The Relationship between Earnings Benchmarks and Earnings Management .....

Dr/ Amr Nazieh Mahmoud Ezat

management tools and their effects on the sampled Egyptian firms' life cycles.

Moreover, a firm's life cycle includes different stages when different activities are performed to achieve certain objectives. One of the most important objectives is the reporting of accounting earnings information. Markets react positively to good news about the earnings since earnings are one of the key indicators for evaluating if the firm has been successful (Kothari, 2001; Graham et al., 2005). Therefore, managers are more sensitive to the reported earnings that may meet or beat the market's expectations. Firms in each stage of their life cycle may apply certain earnings management tools to either avoid the reporting of losses or to extend the reporting of profits regarding their earnings benchmark strategies. Therefore, firms may have incentives to engage in earnings management tools to avoid reporting losses or to reveal the reported profit depending on the characteristics demonstrated in each stage of the firm's 1 life cycle. Accordingly, this study's third objective is to investigate the earnings management tools applied by Egyptian firms in each stage of their life cycles to achieve the desired earnings benchmark.

Accordingly, this study answers the call of recent literature reviews to investigate the impact of earnings management tools on earnings benchmarks across the various stages of Egyptian firms' life cycles. Dechow et al., (2010) argued the need to 
The Relationship between Earnings Benchmarks and Earnings Management .....

Dr/ Amr Nazieh Mahmoud Ezat

investigate unknown firm characteristics that might impact on earnings benchmarks. Consequently, the testing of the impact of the stages of the firm's life cycle on earnings benchmarks is the researchers' attempt to add to the extant accounting literature.

In addition, Habib and Hansen (2008) illustrated the overwhelming trend of empirical research related to the investigation of earnings management around earnings benchmarks. Further, there is the most recent examination of the relationship between earnings management and earnings benchmarks across the stages of the firm's life cycle (Da Silva Roma et al., 2020). Moreover, Habib and Hasan, (2019) reviewed the topic of firm life cycle and recognized researchers' considerable interest in different research areas of accounting and, more especially, its impact on earnings management tools. Previous studies' findings, which focused on Western and Asian countries, have shown that earnings management and quality earnings vary over the firms' life cycles. Consequently, through investigating, and earnings benchmarks in the context of the Middle east area, namely, the Egyptian context. this study seeks to respond to the recent trend in the accounting research area though investigating the relationship between firm life cycle and earnings management,

Turning to this study's first objective, the findings illustrate that earnings bins varies across the stages of the firm's life cycle stage. Each stage has an impact on the Egyptian managers' 
The Relationship between Earnings Benchmarks and Earnings Management .....

Dr/ Amr Nazieh Mahmoud Ezat

attitudes of the to achieve earnings target. In addition, having regard to this study's second objective, the findings demonstrate that the use of earnings management tools, such as AEM and REM, influence the various stages of the firm's life cycle. Egyptian firms' managers can apply different tools of earnings management across the stages of their firms' life cycles. Based on the third objective when investigating the interaction between firm life cycle and earnings management, the findings indicate this has an incremental effect on the various earnings benchmarks. Managers of the various stages of the firm life cycle apply earnings management tools to achieve their earnings targets.

This study contributes to the accounting literature in many (several) ways. First, theoretically, this study introduces a construct based on the life cycle theory, prospect theory, signaling theory and transaction cost theory to justify the relationship between firm life cycle, earnings management and earnings benchmarks. This study examines the impact of the interaction between firm life cycle and earnings management on earnings benchmarks. To a large extent, the previous studies did not examine such a construct. Second and, more specifically Empirically, this study's findings explain the reason why, from a academic perspective, the employment of various earnings management tools in the various stages of life cycle represent an interesting topic that, previously, the academics did not consider 
The Relationship between Earnings Benchmarks and Earnings Management .....

Dr/ Amr Nazieh Mahmoud Ezat

to be remarkable. Third, this study examines the impact of various tools of management for example, AEM and REM, on different earnings benchmarks such as J_BT, BT, J_MS, and MS which have not been examined widely in accounting research. Finally, unlike most previous studies, this study investigates the relationship between earnings management and earnings benchmarks across all the various stages of a firm's life cycle rather than only at specific stages.

Accordingly, by considering such an interesting topic in the context of a developing country, namely Egypt, this study extends the previous studies' findings that examined a firm's life cycle and its impact on different topics in the developed countries. The rest of this paper is organized as follows. Section 2 describes the previous studies' findings and sets out the formulation of this study's hypotheses. Section 3 introduces the research methodology. Section 4 discusses the empirical findings. Finally, section 5 presents the conclusion.

\section{Literature Review and Development of the Hypotheses}

To achieve its main objectives, this study discusses three streams of literature. These are: firm life cycle; earnings benchmark; and earnings management. The following details this study's review of the previous literature about these streams.

\subsection{Firm's Life Cycle Stages}

Firm life cycle theory is derived from the notion of resource based theory that postulates that a firm's capabilities vary over 
The Relationship between Earnings Benchmarks and Earnings Management .....

Dr/ Amr Nazieh Mahmoud Ezat

time and that its growth depends on the effective use of these capabilities and their rational management (Wernerfelt, 1984). Therefore, based on resource theory, firm life cycle theory assumes that managerial decisions in different life cycle stages and the firm's performance are affected by the changes in the firm's resources and how effectively these are managed (Habib and Hasan, 2017).

Life cycle theory states that firms encounter many internal factors (e.g., strategic choices, financial resources, managerial ability, and available capabilities) and external factors (e.g., sever competition, macroeconomic condition) across the various stages of their life cycles (Anderson and Zeithaml, 1984; Dodge and Robbins, 1992; Dickinson, 2011; Li and Zang, 2018). One of the main problems in relation to the stages of a firm's life cycle is the uniqueness of each stage's characteristics. Firms may shift from one early stage to late one and vice versa. This leads to a nonlinear direction and make firm life cycle theory a nondeterministic approach (Elsayed and Patton, 2009; Güleç and Karacaer, 2018). Therefore, accurate determination of the various stages of a firm's life cycle helps its managers to deal with the characteristics of each stage and to signal their performance to different stakeholders (Güleç and Karacaer, 2018). Firms have different stages in their life cycles. This is because they have various distinctive characteristics and objectives that make an obvious impact on each firm's strategy, structure, decision 
The Relationship between Earnings Benchmarks and Earnings Management .....

Dr/ Amr Nazieh Mahmoud Ezat

making methods and value -relevance of accounting measures of performance (Miller and Friesen 1984; Black, 1998; Jenkins et al., 2004; Kallunki and Silvola 2008, Choi et al., 2016). Presented earnings is one of the most valuable pieces of information that varies between each life cycle stage.

In the introduction stage, firms are in their birth phase. They are dominated by their owners and young enough to obtain market acceptance and market share. Therefore, they spent more on innovation activities (to provide unique products), on marketing activities (to advert and promote these products), and on capital activities to increase the capacity that absorbs the production of these products (Miller and Friesen, 1984; Selling and Stickney, 1989; Nagar and Radhakrishan, 2017). Based on Dickinson's (2011) classification of cash flow, operating cash flows are negative (This is because firms have little knowledge about the market and profitable customers.), investing cash flows are also negative (This is because firms make large investments on developing, introducing, and marketing a new product to gain competitive advantages over their competitors and, hence, delay their earlier entry to the market). However, financing cash flows are positive (This is because firms need to have adequate finance to spend on their investments and, therefore, they access bank debt followed by issuance of equity.). Accordingly, at this stage, there are relatively few sales and this leads to negative or little earnings (Selling and Stickney, 1989; Black, 1998). 
The Relationship between Earnings Benchmarks and Earnings Management .....

Dr/ Amr Nazieh Mahmoud Ezat

In the growth stage, the firms begin to build a niche in the market and continue to spend more on innovation, marketing and capital activities to increase their market share. Therefore, firms accelerate and maximize their sales to achieve survival threshold (Black, 1998; Jenkins et al. 2004; Nagar and Radhakrishan, 2017). According to the cash flow attributes, operating cash flows are positive (This is because profit margins are maximized.), and financing cash flows are also positive (This is because firms access bank debt to maintain their opportunities for growth.). However, investments in cash flows are negative (This is because firms continue to increase their investments to deter competitors from entering the market.). Accordingly, earnings begin to turn into positive amounts (Barclay and Smith, 2005; Dickinson, 2011).

In the maturity stage, firms become market leaders and among their competitors they are characterized by stability and increased bargaining power. This is due to the benefits of economies of scale which lead to their improved efficiency and, hence, significantly increased earnings (Selling and Stickney, 1989; Choi et al., 2016). In the mature stage, operating cash flows are positive (This is because profit margins are maximized due to maximized efficiency through increased knowledge of their operations.). However, investing cash flows are negative (This is because, while mature firms reduce their investments, they still bear maintenance capital costs which increase over time with 
The Relationship between Earnings Benchmarks and Earnings Management .....

Dr/ Amr Nazieh Mahmoud Ezat

increased obsolescence.). Similarly, financing cash flows are negative (This is because mature firms do not require to increase their finance and have minimal need for additional borrowing as they begin to gain from what they have accomplished already and shift their focus shifts from acquiring finance to servicing debt and distributing excess funds to shareholders,) (Wernerfelt, 1984; Barclay and Smith, 2005; Dickinson, 2011).

Finally, in the decline stage, firms suffer from recession resulting from the increased competition, the limitation of growth opportunities and smaller market share, events lead to disinvestments and restructuring their activities. Consequently, earnings are reduced (Miller and Friesen, 1984; Selling and Stickney, 1989; Nagar and Radhakrishan, 2017). Turning to the attributes of cash flows attributes, operating cash flows are negative (This is because prices are reduced and result in increased losses are.). However, investing cash flow investments are positive (firms begin to liquidate assets to service debt and to support their operations). Financing cash flows may be negative or positive (This is because declining firms face greater financial distress and focus either on debt repayment or making new debt covenants).

Recently, there has been an increasing trend to examine the relationship between a firm's life cycle and different aspects (Habib and Hasan, 2019), These are: the key determinants of firm life cycle (Agarwal and Audretsch, 2001; Jenkins et al., 2004; 
The Relationship between Earnings Benchmarks and Earnings Management .....

Dr/ Amr Nazieh Mahmoud Ezat

Mata and Freitas, 2012; Warusawitharana, 2018); the value relevance of the firm's financial information (Black, 2003; Habib, 2010; Hribar and Yehuda, 2015; Vorst and Yohn, 2018; Dickinson et al., 2018); the firm's tax posittion (Anandarajan et al., 2010; Stam and Verbeeten, 2017; Hasan et al., 2017); corporate governance (Chiang et al., 2013; Li and Zang, 2018) ; cash holding (Drobetz et al., 2015, Alzoubi, 2019); auditing (Hossain et al., 2019) ; corporate social responsibility (Hasan and Habib, 2017; Lee and Choi, 2018; Hsu and Chen, 2018); and the quality of the firm's financial reporting as measured by different proxies such as sustained earnings (Suberi et al., 2012; Drake, 2012), conservatism (Abdullah and Mohd-Saleh, 2014; Hansen et al., 2018) and readability and tone (Bakarich et al., 2019)).

However, few studies have investigated the associations between firm life cycle and earning management and earnings benchmark. This study seeks to fill the gap. Therefore, the study discusses first, the relationship between firm life cycle and earnings benchmarks, next presents the relationship between firm life cycle and earnings management and, finally, introduces, the relationship between firm life cycle and both earnings benchmarks and earnings management.

\subsection{Firm Life Cycle and Earnings Benchmarks}

Managers may pursue many accounting discretions to realize earnings benchmarking. The motivation for doing so is derived from many reasons such as employee bonuses, bond covenants, 
The Relationship between Earnings Benchmarks and Earnings Management .....

Dr/ Amr Nazieh Mahmoud Ezat

stakeholder motivation and stock price motivation (Graham et al., 2005). Consequently, earnings benchmark is one of the most valuable performance targets (Choi et al., 2016). Accounting earnings represent the initial information in the financial statements that are considered by shareholders (Habib and Hansen, 2008).

Following (Roychowdhury, 2006; Nagar and Radhakrishan, 2017), this study utilizes four earnings bins to reflect earnings benchmarking. These are namely, Just Beat (J_BT), Just Meet (J_MT), Beat (BT) and Meet (MT). The measurement of these bins is based on the net income scaled by total assets at the beginning around the zero earnings level as mentioned later.

A review of the literature related to the influence of a firm's life cycle on its earnings benchmark demonstrates that few accounting studies examined such a relationship. Dickinson (2011) constructed a firm life cycle proxy that depended on the cash flow patterns. This proxy identified various behaviors regarding the persistence and convergence of either current or future profitability patterns. The findings of Dickinson's study conclude that firm life cycle clarifies the variation in the convergence and persistence of current profitability among the various stages of a firm's life cycle. In addition, Dickinson's study findings reveal a justification for the impact of a firm's life cycle on its future profitability. This study concentrated mainly on the beat side and ignored the various types of earnings benchmarking. 
The Relationship between Earnings Benchmarks and Earnings Management .....

Dr/ Amr Nazieh Mahmoud Ezat

In their study, Choi et al., (2016) explore if and how a firm's life cycle impacts empirically on the earning benchmark. This study concentrates mainly on the two stages of a firm life cycle. These are: namely, growth; and maturity. Earnings benchmark is measured by three indicators. These are: meet or beat zero earnings; previous earnings; and analysts' forecasts of future earnings. The results indicate that a firm's life cycle plays a crucial role in it either meeting or beating the earnings benchmark. More specifically, growth firms are more likely to meet or beat all the three earnings benchmarks. Consequently, Choi et al.'s study findings provide evidence of the influence of a firm's life cycle on its earnings benchmark. In addition, it suggests that, when considering a firm's life cycle better evaluation is required of the consequences of adopting earnings benchmarking.

Earnings benchmark is among the important performance targets that firms seek to achieve and apply due to its consequences on a firm's various decisions on actions and on the market's reaction (e.g., stock price) (Kasznik and McNichols, 2002; Skinner and Sloan, 2002; Chevis et al., 2007), as well as its impact on the firm's current and future performance (Bartove et al., 2002; Graham et al., 2005).

There are many reasons that explain the impact of a firm's life cycle on its earnings benchmark (Choi et al., 2016). First, there is the market's various reactions -represented in the volatility of 
The Relationship between Earnings Benchmarks and Earnings Management .....

Dr/ Amr Nazieh Mahmoud Ezat

stock price- when the firm meets or misses its earnings target. This market reaction differs across the different stages of a firm's life cycle due to its various objectives and the situations in the market. Ertimure et al.'s (2003) findings demonstrate that, in terms of earnings surprises, the reactions of investors' behaviors \# vary according to the firm's life cycle stage. Further, Skinner and Sloan's (2002) findings support this view by indicating that missing its earnings benchmark can lead investors to adjust their expectations about the firm's future.

Second, there is the need to raise capital to achieve the planned objectives in each stage of the firm's life cycle. In each cycle, a firm needs to acquire the required capital to achieve its strategy. The earnings announcement is one of the crucial signals to attracting capital providers since it gives more confidence about the firm's survival (Bartov et al., 2002). Therefore, a firm meeting or beating its earnings benchmark provides a good signal to obtaining the required capital in the different stages of the firm's life cycle.

Third, there is the uncertainty related to each firm's life cycle stages in terms of future payoffs. Previous studies' findings demonstrate the impact of beating earnings benchmarks in respect of firms with greater uncertainty regarding the cost of capital. Many studies' findings have indicated the impact of beating earnings on bondholders' future payoffs (Burgstahler and Dichev, 1997; Degeorge et al.,1999; Jaing, 2008; Zhang, 2018) and, hence, this 
The Relationship between Earnings Benchmarks and Earnings Management .....

Dr/ Amr Nazieh Mahmoud Ezat

provides the biggest reward in terms of the lower cost of debt. Similarly, previous studies have concentrated on the association between beating earnings benchmarks and equity capital (Kasnik and McNichols, 2002; Bartov et al., 2002; Jensen, 2005; Koonce and Lipe, 2010). Therefore, meeting or beating earnings in the different stages of a firm's life cycle may motivate it to manage its cost of capital to achieve the desired objectives.

Based on psychological perspective of prospect theory, individuals are more satisfied when their wealth changes from losses to gains around natural reference points. This is because losses cause more unpleasant situations than the equivalent gain. Therefore, investors may be more confident in the firms that report a series of small gains instead of firms that report unstable earnings (Kahneman and Tversky, 1979; Koonce and Mercer, 2005; Habib and Hansen, 2008). Consequently, managers prefer to signal their ability to beat the earnings around a certain point in each stage of a firm's life cycle since this shows the firm's unique characteristics in achieving its objectives. Accordingly, the first hypothesis is:

\section{H1: There is a significant relationship between Egyptian} firms' life cycles and their earnings benchmarks.

\subsection{Firm Life Cycle and Earnings Management}

Earnings play a crucial role in reflecting the firm's success in the business world. Earnings aid firms to perform their developments and to achieve their objectives by attaining several purposes such as: 
The Relationship between Earnings Benchmarks and Earnings Management .....

Dr/ Amr Nazieh Mahmoud Ezat

granting bonuses to managers; recognizing taxable income for government purposes; and evaluating the progress in the firm's performance (Zamrudah and Salaman, 2013). Therefore, mangers are more likely to manage earnings through using their judgment in the financial reporting and by constructing transaction in the way that may modify the outcome of financial reports by manipulating the presented accounting numbers to mask the firm's actual performance (Healy and Wahlen 1999, Nagar and Sen, 2017). Managers can use many tools to manage the firm's earnings. These tools are such as: accrual earnings management (AEM) (e.g., Healy and Wahlen, 1999; Fields et al., 2001; Dechow et al., 2010); real earnings management (REM) (e.g., Roychowdhury, 2006; Kuo et al., 2014; Chung et al., 2015); and classification shifting (CS) (e.g., McVay ,2006; Fan et al., 2010; Zalata and Roberts, 2017). In the Egyptian context, this study concentrates mainly on the first two tools.

The various levels of profit generated in each stage of a firm's life cycle explain the importance of managers using an earnings management tool to alter the presented earnings in each stage of the firm's life cycle. As mentioned, previously, each life cycle stage has different characteristics and various reported profits depending on the objectives needed to be achieved in each stage.

The duration of a firm's life cycle stages differs markedly among firms within the same industry (Dickinson, 2011). There are many reasons to explain this variation. One example is the enormous competition in multiple industries that forces firms to 
The Relationship between Earnings Benchmarks and Earnings Management .....

Dr/ Amr Nazieh Mahmoud Ezat

introduce diverse products which increase the overlap between the life cycle stages and, hence, the difficulty of assessing them. Further, within an industry, each stage varies in each firm due to the variation of knowledge acquisition, the level of investments and the variations of some financial ratios and accounting figures. Consequently, it is difficult to believe that all managers in the various stages of the firm's life cycle will share the same incentives and motivations to manage earnings (Chen et al., 2010). Earnings is one of the factors that demonstrates significant variations in the stages of the firm's life cycle (Chen and Huang, 2008). Therefore, this study aims to explain the potential relationship between earnings management and firm life cycle.

Few studies have examined the relationship between earnings management and firm life cycle. By sampling firms, listed on the Compustat Industrial Annual databases during the period from 1960 to 2004, Liu (2006) explored the association between firm's life cycle and abnormal discretionary accrual as a measurement of earnings management. This study's findings argue that firms in their growing stages have different accrual properties than those in their maturity and declining stages. The findings support this argument by indicating that growing firms have more abnormal accrual than mature and declining firms. This implies that managers in these growing firms are motivated to engage in earnings management behaviors.

By investigating China's listed firms in the period from 1998 
The Relationship between Earnings Benchmarks and Earnings Management .....

Dr/ Amr Nazieh Mahmoud Ezat

to 2005, Chen et al., (2010) tested if the incorporation of a firm's life cycle stages into the model of accrual improved its explanatory power. They employed various accrual models in addition to many control variables. Their study's results show that the coefficient of introduction and growth stages are positive and significant at the $1 \%$ level, whereas the coefficient of the decline stage is negative and significant. This study's results suggest that firms in the introduction and growth (decline) stages have strong (weak) motivation to manage earnings higher (lower) than those in the maturity stage. Accordingly, managers have different incentives to engage in earnings management at the various stages of a firm's life cycle.

From investigating the various stages of Taiwanese firms' life cycles in the period from 1996 to 2006, Shiue et al., (2012) analyzed if there were differences in the REM. The findings report that, when compared to those firms in the other stages, firms in the growth stages implemented REM to a lesser extent. Accordingly, the study's findings suggest that, when compared to those managers in the other stages, managers in the growth stage are more (less) likely to engage in AEM (REM).

By using a sample of non-financial firms listed on the Tokyo Stock Exchange in the period from 2007 to 2013, Pachariyanon (2014) examined the association between the firm life cycle and the choice of AEM and REM. This study's results reveal that in the introduction and growth stages of a firm's life cycle managers 
The Relationship between Earnings Benchmarks and Earnings Management .....

Dr/ Amr Nazieh Mahmoud Ezat

have more incentives to use AEM than REM to manage its earnings. This study's results provide empirical evidence of the impact of managers choosing between two earnings management tools, namely AEM and REM, in only the introduction and growth stages of a firm's life cycle.

By using a sample that included NYSE, AMEX, and NASDAQ non-financial firms in the period from 1973 to 2009, Hribar and Yehuda (2015) tested the mispricing of total accrualbased accounting information at the different stages of a firm's life cycle. The findings illustrate that there is a weak correlation between total accrual and the firm's growth stage and that this correlation becomes greater for firms in the maturity and decline stages. This finding exhibit demonstrates that managers of a firm in the growth stage have less incentives to manipulate accruals than managers of firms in the maturity and decline stages.

Based on a sample of American firms in the period from 1988 to 2012, Chang (2015) analyzed an alternative identification of estimation samples by using a firm's life cycle to detect accrual manipulation. This study's findings show that life cycle-based estimation samples improve the power of detection in the studied sample. For accrual manipulation, the power of detection varies across the life cycle stages since the reported coefficient shows the relationship between various economic drivers and total accruals. Further, the findings demonstrate that, when compared to the other two life cycle stages, firms in the maturity stage have 
The Relationship between Earnings Benchmarks and Earnings Management .....

Dr/ Amr Nazieh Mahmoud Ezat

the lowest total accrual. This suggests that, when compared to the other two life cycle stages, this stage has the lowest level of earnings management.

In China, based on the life cycle perspective for firms listed on the Shanghai and Shenzhen A-share Stock Exchange in the period from 2010 to 2013, Chen (2016) tested if internal controls restrained earnings management. Chen's study used both AEM and REM as indicators of earnings management. The findings illustrate that, in different stages of a firm's life cycle, the greater the quality of internal control, the lesser the level of AER and REM. Moreover, this study's findings provide empirical evidence that, when compared to AER, in the growth and mature stages, a firm's managers have more incentives to engage in REM.

By using a 502 observation panel data of the Indonesian capital stock exchange in the period from 2010 to 2014, Hastuti et al., (2017) studied the potential impact of a firm's life cycle on earnings management combined with the internal control system to moderate such a relationship. This study's findings show that a firm's life cycle has no impact on accruals earnings management. Further, when the firm's internal control system interacts with the firm's life cycle, its coefficient becomes significant. This suggests that the internal control system has the capability to weaken the positive impact of the firm's life cycle on accrual earnings management. 
The Relationship between Earnings Benchmarks and Earnings Management .....

Dr/ Amr Nazieh Mahmoud Ezat

Hansen et al., (2018) examined if a firm's life cycle stages impacted on its reporting conservatism depending on the firmsyear observations from the intersection of the COMPUSTAT and CRSP databases covering the period from 1988 to 2012. This study employed three measures for accounting conservatism; one of them is non-operating accrual. This study's findings demonstrate that, in the earlier stages of a firm's life cycle i.e., introduction and growth, managers are more engaged in managing earnings than those in the firm's later stages i.e., maturity and decline.

Among other indicators, Krishnan et al., (2018) investigated the relationship between accrual accounting as a proxy of financial reporting quality and a firm's life cycle. The study examined the impact of each stage of the life cycle, namely. introduction, growth, maturity and decline on the sampled firms' use of accrual in the period from 1988 to 2012. This study's findings show that, when compared to the maturity stage, the other stages have higher absolute values of abnormal accrual. This finding indicates that firms in the introduction, growth, and decline stages are more likely to manage earnings than firms in the maturity stage.

By using a sample of American listed companies in the period from 1988 to 2016, Kale and Almeida (2019) analyzed the role of a firm's life cycle stage on the quality of accruals. This study's findings highlight that firms in introduction and decline 
The Relationship between Earnings Benchmarks and Earnings Management .....

Dr/ Amr Nazieh Mahmoud Ezat

(growth and mature) stages have a lower (higher) quality of reported accruals. Further, when compared to growth and mature firms, introduction firms have higher long-term accrual. This finding denotes that. when compared to growth and mature firms, managers in introduction and decline firms are more likely to engage in earnings management behaviors. This finding supports the impact of a firm's life cycle on earnings management.

Da Silva Roma et al., (2020) reviewed the impacts of the accrual-based earnings management and economic uncertainty on the firm life cycle of listed American and Brazilian firms. For both samples, the findings indicate that, when compared to those in the growth and mature life cycles firms, which are in the introduction and decline stages of a firm's life cycle, are more inclined to employ accrual earnings management.

Hussain et al., (2020) investigated if the Chinese firms' managers' tendencies varied through the different stages of a firm's life cycle. The study employed panel data fixed -effects and random -effects techniques to estimate regression models for non-financial Chinese listed firms in the period from 2009 to 2018. This study's findings reveal that, opportunistically, managers changed their propensity towards EM practices through the various stages of the firm's life cycle. More specifically, this study provides empirical evidence that at the introduction and decline stages managers have more propensity to use both AEM and REM practices to manipulate earnings. On the other hand, 
The Relationship between Earnings Benchmarks and Earnings Management .....

Dr/ Amr Nazieh Mahmoud Ezat

there is no empirical evidence that in the firms' growth and maturity stages Chinese managers use any kind of EM practices.

In the context of Turkey, Can (2020) considered the impact of the quality of financial reporting, as measured by discretionary accruals, on listed Turkish firms between 2008 and 2017. By reporting a negative coefficient for discretionary accruals, this study's findings suggest that earnings management by managers reduced as their firms moved forward in their life cycle stages. However, this coefficient was not statistically significant.

Most recently, Michalkova (2021) explored the influence of life cycle and country specific factors, as measured by discretionary accrual, on earnings management behaviurs of tourism sector firms in Central European countries (the Czech Republic, Hungary, Poland, and Slovakia). This study used the method of two-way analysis of variance with interaction depending on a sample of 3650 companies in the period from 2018 to 2020. This study's findings indicate that earnings management changed remarkably during the different stages of firm's life cycle and across different countries. In detail, firms in their mature and declined stages employed more significant downward earnings management techniques than at the other stages. These findings suggest that a firm's life cycle has a significant impact on its level of earnings management.

Managers are expected to receive incentives for managing earnings in the different stages of a firm's life cycle. In the 
The Relationship between Earnings Benchmarks and Earnings Management .....

Dr/ Amr Nazieh Mahmoud Ezat

introduction stage, there are two points of views as to whether or not managers are more likely to manage earnings. On the one hand, firms need to provide good signals to their shareholders and lenders about their future growth. Therefore, these may explain the incentives of managers to manage earnings by using discretion in reported numbers to present improvements in earnings (Hasan et al., 2017; Da Silva Roma et al., 2020). On the other hand, firms in the introduction stage and, unlike in other stages, may not suffer from investor pressure to discloses profits. This is because, at the introduction stage, investors concentrate mainly on the rate of innovation and market branding activities (Krishnan et al., 2018).

In the growth stage, managers are more likely to manipulate earnings to meet the investors' expectations about the firms' future earnings as derived from their assumptions about the profits to be gained at this stage. Previous studies' findings provide empirical evidence about the incentives received by managers in the growth stage to manage earnings (e.g., Lee et al., 2006; Madhogarhia et al. 2009; Houmes and Skantz, 2010; Choi et al., 2016; Nabar and Song 2017). In contrast, few studies' findings have illustrated the opposite view that firms may not be forced to report losses in their reports due to the lack of investors' overreaction on reporting losses. Therefore, growth firms may not need to manage earnings and instead they can disclose losses in their reports (Black, 1998; Charitou et al., 2011). 
The Relationship between Earnings Benchmarks and Earnings Management .....

Dr/ Amr Nazieh Mahmoud Ezat

The firm's maturity stage is characterized by the reduced risks and uncertainties about future earnings. Consequently, managers are less likely to engage in earnings management (Krishnan et al., 2018). However, due to the experiences of such firms in the market and their leadership, the market may expect high earnings at the maturity stage. Accordingly, this places pressure on mangers to manage earnings to meet these expectations (Graham et al., 2005).

In the decline stage, firms may engage in earnings management tools to avoid the violation of debt covenants (DeFond and Jiambalvo (1994) and to hide the bad signals of earnings due to the distress that these firms are suffering at this stage (Krishnan et al., 2018).

Each stage of a firm's life cycle has various objective and characteristics that result in various level of earnings and generate uncertainty in its cash flow. Based on signaling theory, mangers of each stage of a firm's life cycle need to signal the good performance to fulfil the requirements of such stage and, hence, increase the firm's efficiency. To achieve this, managers use different tools of earnings management.

Based on the above arguments, firms in different stages of their life cycles may have different incentives to use earnings management tools. At each stage, firms may be motivated to manage earnings upwards or downwards to fulfil their objectives and to respond to these requirements that assure their survival in the market. Accordingly, the second hypothesis is: 
The Relationship between Earnings Benchmarks and Earnings Management .....

Dr/ Amr Nazieh Mahmoud Ezat

\section{H2: There is a significant relationship between Egyptian} firms' life cycles and earnings management.

\subsection{Firm Life Cycle, Earnings Benchmarking and Earnings Management}

An increasing body of empirical studies have presented the incentives of mangers to mask the true economic performance of their firms through conducting different tools of earnings management (such as: AEM, REM, and CS). They take such actions either to avoid the reporting of losses and reduced earnings decrease (e.g., Burgstahler and Dichev, 1997; Degeorge et al., 1999; Skinner and Sloan, 2002; McVay, 2006; Gore et al., 2007; Koh et al., 2008; Bartov et al., 2009; Osma and Young, 2009; Barua et al., 2010; Fan et al., 2010) or to meet accounting targets (i.e., Graham et al., (2005)).

Phillips et al., (2003) have determined many earnings thresholds that motivate managers to engage in earnings management. Among them is the avoidance of reporting either reduced earnings or losses. Further, Fan et al., (2010) report that the motivations for managers to meet or beat earnings benchmarks encourage them to employ a classification shifting tool to manipulate earnings. In addition, Nagar and Sen (2017)'s findings demonstrate the motivations of Indian firms' mangers to manipulate earnings by using classification shifting to meet or beat zero or - previous period core earnings. In the same vein, Bartov et al., (2002) mention the influence of earnings 
The Relationship between Earnings Benchmarks and Earnings Management .....

Dr/ Amr Nazieh Mahmoud Ezat

benchmarks on stock returns and report that firms, which meet or beat earnings benchmarks, have higher stock returns when compared to those that fail to achieve the earnings benchmarks.

However, few studies have investigated the earnings benchmarking as a motivation to apply earnings management tools across the different stages of a firm's life cycle. Mcvay (2006) introduced the relationship between classification shifting as a tool for earnings management and earnings benchmarks for high growth American firms to meet or beat analysts' forecasts. Her findings show that managers of high growth firms have increased incentives to use classification shifting to meet or beat earnings benchmarks.

By examining the growth and maturity stages of Indonesian firms' life cycles in the period from 2000 to 2007, Zamrudah and Salman (2013) examined the role of accrual in exploring earnings management to avoid the disclosure of losses and the reporting of declining earnings declining 2000 to 2007. Their findings indicate that, when firms reporting earnings decline, the accrual tool does not support the detecting of earnings management in the growth and mature stages. However, when firms reporting losses, accrual has a significant effect in detecting earnings management only in the growth stage and not in the maturity stage.

Nagar and Sen (2016) explored if Indian listed firms in the decline stage of their life cycle in the period from 1996 and 2011 engaged in earnings management. They employed classification 
The Relationship between Earnings Benchmarks and Earnings Management .....

Dr/ Amr Nazieh Mahmoud Ezat

shifting tool as an indicator for managing earnings by. Their findings illustrate that Indian listed firms in the decline stage are more likely to engage in earnings management. This is achieved by manipulating core or operating income through classification shifting of operating expenses to avoid disclosing losses.

Based on the above studies' findings, it is apparent that few studies have investigated the association between earnings management and earnings benchmarks in the different stages of life cycle. Moreover, the studies, which examined the three variables, concentrated on some and not all stages of the life cycle. Further, the comparison between AEM and REM in different stages of firm life cycle to meet or beat earnings benchmarks is missing from the previous studies. Consequently, this study investigates the motivation of Egyptian firms' managers to apply earnings management tools to achieve the earnings benchmarks through the various stages of a firm's life cycle.

Mixed explanations and conclusions have been reported about the incentives of earning benchmark and earnings management in the various stages of a firm's life cycle. There is one point of view that, when firms have more incentives to meet or beat earnings, they have more incentives to manage earnings in the different stages of their life cycles. The other point of view is that various stages of a firm's life cycle have unique characteristics that may encourage the managers to discard earnings management through the various stages of life cycle to achieve earnings benchmarks. 
The Relationship between Earnings Benchmarks and Earnings Management .....

Dr/ Amr Nazieh Mahmoud Ezat

In the introduction stage, firms concentrate mainly on enforcing their existence in the market by spending more money on innovation and market branding activities (Nagar and Radhakrishan, 2017). In addition, the firms suffer from low sales and, hence, low profits or even suffer losses. At this stage, firms are less likely to manage earnings since there is no pressure from their investors to be profitable (Choi et al., 2016). Accordingly, in the introduction stage, firms may use the strategy of meeting or just meeting earnings and, therefore, managers are less likely to manage earnings. In contrast, in the introduction stage, managers may have the incentives to beat or just beat their earnings to convince their stakeholders about their firms' futures and present good opportunities for investment in their firms due to the prospects for future growth. Therefore, this may lead managers in the introduction stage to manage earnings to beat or just beat the firm's earnings (Krishnan, 2018)

In the growth stage, firms increase their acceptance among competitors; achieve a considerable foothold in the market (Nagar and Radhakrishan, 2017); and continue to increase their investments in innovations and market activities to raise their market share. Further, in the growth stage, firms are motivated to maximize their sales and, hence, increase their profits in relative terms. Accordingly, there are many reasons to explain the managers' motivations in the growth stage to meet or beat earnings. Among them (Choi et al., 2016), there are the market's 
The Relationship between Earnings Benchmarks and Earnings Management .....

Dr/ Amr Nazieh Mahmoud Ezat

asymmetric reactions when firms meet or beat earnings benchmarks; the need to raise capital to achieve the various objectives required in the growth stage; the necessity to reduce the cost of capital; and, finally, to send a positive signal to the investors about the firm's future performance. Therefore, managers in the growth firms are motivated to engage in earnings management to guarantee the continuous of their future performance. Accordingly, they report this to their stakeholders who, in the growth stage, expect the firm to perform well Based on the above- mentioned reasons, managers in the growth firms are more likely to manage earnings to beat or meet earnings benchmarks. However, on the other hand and unlike their counterparts in introductory stage firms, managers in the growth firms may not face pressure to meet or beat earnings due to the nature of this stage which lets investors reduce their expectations about earnings (Krishnan et al., 2018). Further, in the growth stage, firms need to maintain or increase their spending on innovation and market activities. Therefore, they are less likely to cut spending in these activities and, hence, perform earnings management (Nagar and Radhakrishan, 2017). Accordingly, in the growth stage, managers may have less incentives to meet or beat earnings benchmarks through applying earnings management.

In the maturity stage, firms begin to reap the benefits of stability and have a power in the market due to their leadership. 
The Relationship between Earnings Benchmarks and Earnings Management .....

Dr/ Amr Nazieh Mahmoud Ezat

In addition, sales are maximized and profits are high. In maturity stage, firms' managers accumulate profits and retain earnings and face fewer risks and uncertainty (Owen and Yawson, 2010). Therefore, they do not need to increase profits and, hence, at this stage, managers are less likely to engage in earnings management (Krishnan et al., 2018). On the other hand, maturity firms have greater experience in the market and reach a high level of leadership. Therefore, this leads investors to expect a high level of performance and profits and, in turn, this pressurizes these firms to beat their earnings level to achieve these expectations. In addition, in the maturity stage, managers have more incentives to meet earnings targets to safeguard their reputations and creditability in the market among investors (Graham et al., 2005; Nagar and Radhakrishan, 2017). Therefore, this encourages managers to manage earnings to achieve the earnings target.

In the decline stage, firms begin to suffer from enormous competition that results in fewer sales and poorer performance and lower profits. Consequently, in the decline stage, firms are more likely to be in financial distress (Nagar and Sen, 2017). Accordingly, in the decline stage, firms need to conceal their poor signs to keep their debt covenants. Further, Bartov et al., (2002) argue that declining firms meeting or beating their earnings benchmarks provide good signs that they will survive in the market. Therefore, in the decline stage, managers are more likely to meet their earnings targets through engaging in earnings management. 
The Relationship between Earnings Benchmarks and Earnings Management .....

Dr/ Amr Nazieh Mahmoud Ezat

Based on the transaction cost theory, managers are more likely to meet or beat benchmarks. Stakeholders need ongoing information to assess the firm's financial ability to achieve its suggested claims. Further, stakeholders are influenced by the firm's financial image that reflects its financial condition, which, in turn, affects its ability and the certainty to make payoffs to its stakeholders. Consequently, managers may adjust the reported earnings to meet or beat earnings benchmarks to increase their creditability to fulfil stakeholders' expectations (Burgstahler and Dichev, 1997; Cornell and Shapiro, 1987; Bartov et al., 2002). Managers are encouraged to apply earnings management to avoid reporting losses in their financial statements (Phillips et al., 2003; Zamrudah and Salman,2013). Accordingly, the opportunistic incentives for managers explain their behaviors to engage in earnings management tools around earnings thresholds the (Dechow and Skinner, 2000).

Consequently, due to the mixed motivations discussed later, this study investigates the relationship between earning benchmarks and earnings management in the various stages of a firm's life cycle. This relationship is based on the following hypothesis: 
The Relationship between Earnings Benchmarks and Earnings Management .....

Dr/ Amr Nazieh Mahmoud Ezat

H3: There is a significant relationship between earnings management and earnings benchmarks in the various stages of Egyptian firms' life cycles.

\section{Methodology}

\subsection{Sample}

The initial sample includes all Egyptian listed firms in the period from 2016 to 2019. I collected the data, used in this study's testing and analysis, from the Egypt for Information Dissemination (EGID) database and the websites of the listed Egyptian firms. Some observations were unavailable and, therefore, I excluded them from the analysis. In addition, some Egyptian firms either listed or delisted recently and this might have caused inequality in the observations of the study period. Therefore, excluded these firms' observations and, therefore, I included only the firms that had full four-year observations. Consequently, the final sample includes 648 observations. Table 1 summarizes the steps followed to obtain the final sample.

Table 1: The initial and final sample

\begin{tabular}{|l|c|}
\hline \multicolumn{1}{|c|}{ Description } & $\begin{array}{c}\text { Number of } \\
\text { observations }\end{array}$ \\
\hline Initial sample (all listed firms from 2016 to 2019) & 679 \\
\hline Less: & 28 \\
some firms listed or delisted within the study period & 3 \\
Less: unavailable observations & $(31)$ \\
\hline & 648 \\
\hline Final Size & \\
\hline
\end{tabular}


The Relationship between Earnings Benchmarks and Earnings Management .....

Dr/ Amr Nazieh Mahmoud Ezat

\subsection{Research Design}

\subsubsection{Measurement of Firm's Life Cycle}

Determining the various stages of a firm's life cycle is a complicated process. This is due to the firm's numerous products that characterize its unique and distinct features. In addition, a firm may have many product lines that makes the transition between the stages of its life cycle more difficult and there may be some overlapping between them (Dickinson, 2011; Faff et al., 2016; Habib and Hasan, 2019). Consequently, empirical studies provide inconsistent measures of a firm's life cycle.

Many studies have introduced different proxies to measure the stages of a firm's life cycle. For example, on the one hand, some studies have introduced one proxy such as firm age (DeAngelo et al., 2010); market value/book value (Jaafar and halim, 2016); and retained earnings (DeAngelo et al., 2006). On the other hand, other studies have employed a composite proxy to measure the stages of a firm's life cycle. The composite proxy includes: firm age; sales growth; dividend yield; and capital expenditures (Anthony and Ramesh, 1992; Zhipeng and Zhao, 2010; Faff et al., 2016; Hastuti et al., 2017). Some studies have used the same composite proxy but have replaced dividend payments with retained earnings ( $\mathrm{Li}$ and Zang, 2018). However, some studies have used only three variables to constitute composite proxy. These are: namely, percent sales growth; dividend payments per year as a percentage of the profit (or percentage of capital 
The Relationship between Earnings Benchmarks and Earnings Management .....

Dr/ Amr Nazieh Mahmoud Ezat

expenditures to the firm's total value); and the firm's age (Shiue et al., 2012; Zamrudah and Salman, 2013, P.5).

Most empirical studies have followed Dickinson (2011) who introduced cash flows pattern classification to measure a firm's life cycle due to its impact on the firm's profitability, growth and risk (Koh et al, 2015; Choi et al., 2016; Hasan et al., 2017; Nagar and Radhakrishan, 2017; Nagar and Sen, 2017; Hussain et al., 2020; Da Silva Roma et al., 2020; Krishnan et al., 2021). Dickinson (2011) used Cash Flow from Operating (CFO), investing (CFI), and financing (CFF) activities as indicators for the purpose of dividing a firm life cycle into five stages. These are: Introduction (IN), Growth (GW), Maturity (MU), shake out, and Decline (DC). This study follows most previous studies in the life cycle field by using Dickinson's (2011) model to classify the various stages of a firm's life cycle but only into four stages, (IN), (GW), (MU), and (DC) (Nagar and Radhakrishan, 2017). I excluded the shake out stage because it is theoretically ambiguous and has no clear direction for $(+)$ and (-) (Dickinson, 2011; Hasan et al., 2017; Choi et al., 2016), Also, by doing so, this study avoids the multicollinearity problems. Based on her identification of a firm's life cycle, I based the classification of the firms' various stages of the life cycle on their cash flows pattern as: (IN) if firms had negative cash flows from operating and investing activities and positive cash flows from financing activities; (GW) if firms had positive cash flows from operating 
The Relationship between Earnings Benchmarks and Earnings Management .....

Dr/ Amr Nazieh Mahmoud Ezat

and financing activities and negative cash flows from investing activities; (MU) if firms had negative cash flow from investing and financing activities and positive cash flows from operating activities; and (DC) for the remaining firms. Table 2 summarizes the combination of these stages.

Table 2: the classification of firm life cycle based on cash flow activities

\begin{tabular}{|l|l|l|l|l|}
\hline Cash Flows pattern & IN & GW & MU & DC \\
\hline CFO & - & + & + & $-,(+),(+),(-),(-)$ \\
\hline CFI & - & - & - & $-,(+),(+),(+),(+)$ \\
\hline CFF & + & + & - & $-,(+),(-),(+),(-)$ \\
\hline
\end{tabular}

\subsubsection{Measurement of Earnings Management}

I employed two tools in this study to measure earnings management. These are: Accrual Earnings Management (AEM); and Real Earnings Management (REM). I used performanceadjusted modified jones model to measure AEM (Kothari et al., 2005; Da Silva Roma et al., 2020; Hussain et al., 2020) as follows:

$\begin{aligned} T A C C_{i t} / T A_{i t-1}= & \alpha_{0}+\alpha_{1}\left(1 / T A_{i t-1}\right)+\alpha_{2}\left(\Delta R E V_{i t}-\Delta R E C_{i t}\right) / T A_{i t-1}+ \\ & \alpha_{3}\left(R O A_{i t-1} / T A_{i t-1}\right)+\alpha_{4}\left(P P E_{i t} / T A_{i t-1}\right)+\varepsilon_{i t}\end{aligned}$

Where $\alpha 0$ is the intercept; TACC $\mathrm{T}_{\mathrm{it}}$ the total accruals (measured as income of firm ' $i$ ' at time ' $t$ ' minus operating cash flow of firm ' $i$ ' at time ' $t$ '; $T A_{i t-1}$ is the total assets of the previous year; $\triangle \mathrm{REV}_{\text {it }}$ is the change in net revenue (measured as the change in net sales from year ${ }_{t-1}$ to year $\left.{ }_{t}\right) ; \Delta \mathrm{REC}_{\mathrm{it}}$ is the change in account receivables (measured as the change in net account receivables 
The Relationship between Earnings Benchmarks and Earnings Management .....

Dr/ Amr Nazieh Mahmoud Ezat

from year ${ }_{t-1}$ to year $\left.{ }_{t}\right) ; \mathrm{ROA}_{\mathrm{it}-1}$ is the ROA for the previous year (net income/ total assets); $\mathrm{PPE}_{\mathrm{it}}$ is the property, plant and equipment (collected from balance sheets as gross fixed assets for the company in that year), $\varepsilon_{i t}$ is the residual value which capture the level of discretionary accruals and hence represents the proxy of AEM. As noted from the previous model, all variables should be deflated by the previous year's total assets.

In this study, I used REM as the other tool of earnings management and, as with previous studies (Cohen and Zarowin, 2010; Zamri et al., 2013; and Hussain et al., 2020), I used Roychowdhury's (2006) model to measure the firms' REM practices. I used three main metrics to denote REM activities and these were, namely: Abnormal Cash- Flows from Operations (ABCFO); Abnormal Production Cost (ABPROD); and Abnormal Discretionary Expenses (ABDIX). I used the following models to obtain these proxies:

The first model captured the $\mathrm{ABCFO}$ and represented the proxy for sales manipulation as the first REM activity. ABCFO can be obtained from the following model:

$$
C F O_{t i}=\beta 0\left(1 / \text { TA }_{t-1}\right)+\beta 1\left(\text { Sales }_{t i}\right)+\beta 2(\Delta \text { Sales })+\epsilon_{t i}
$$

Where $\mathrm{CFO}_{\mathrm{ti}}$ is the cash flows from operations, $\mathrm{TA}_{\mathrm{t}-1}$ is the total assets of the previous year, Sales $_{\mathrm{ti}}$ is the current year sales, $\Delta$ Sales is change in sales from prior year. All variables are scaled by prior year total assets. $€_{\mathrm{ti}}$ is the residual value which capture the (ABCFO). 
The Relationship between Earnings Benchmarks and Earnings Management .....

Dr/ Amr Nazieh Mahmoud Ezat

The second model captures the (ABPROD) and represents the proxy for overproduction manipulation as second REM activity. ABPROD can be obtained from the following model:

$\operatorname{PROD}_{t i}=\beta 0\left(1 /\right.$ TA $\left._{t-1}\right)+\beta 1 \quad\left(\right.$ Sales $\left._{t}\right)+\beta 2\left(\Delta\right.$ Sales $\left._{t}\right)+$ $\beta 3\left(\Delta\right.$ Sales $\left._{t-1}\right)+\epsilon_{t i}$

Where $\mathrm{PROD}_{\mathrm{ti}}$ is the production costs (cost of goods sold (COGS) $+\Delta$ Inventory), all variables are scaled by prior year total assets. $\epsilon_{\mathrm{ti}}$ is the residual value which capture the (ABPROD).

The third model captures the (ABDIX) and represents the proxy for manipulation of discretionary expenditure as third REM activity. ABDIX can be obtained from the following model:

$$
\operatorname{DISX}_{t-1}=\beta 0\left(1 / \text { TA }_{t-1}\right)+\beta 1\left(\text { Sales }_{t-1}\right)+\epsilon_{t-1}
$$

Where DISX $\mathrm{D}_{\mathrm{t}-1}$ is the discretionary expenses, all variables are scaled by prior year total assets. $€_{\mathrm{ti}}$ is the residual value which capture the (ABDIX).

Thereafter, I obtained a comprehensive REM proxy by calculating the sum of the above three REM metrics (ABCFO + ABPROD - ABDISX).

\subsubsection{Measurement of Earnings Benchmarks}

Following Roychowdhury (2006) and Nagar and Radhakrishan (2017), I introduced in this study four earnings bins to measure earnings benchmark. These were: Beat (BT) for firms that beat the earnings benchmark and reported large profits; Just Beat 
The Relationship between Earnings Benchmarks and Earnings Management .....

Dr/ Amr Nazieh Mahmoud Ezat

(J_BT) for firms that just met the earnings benchmark and reported small profits; Miss (MS) for firms that missed the earnings benchmark and reported large losses; and Just Miss (J_MS) for firms that just missed the earnings benchmark and reported small losses. By using the percentage of net income (NI) over beginning total assets (ASSET $\mathrm{t}_{-1}$ ), earnings benchmarks have classified as follows:

(BT) if firm-years with $\mathrm{N}_{\mathrm{It}} / \mathrm{ASSET}_{\mathrm{t}-1}$ is $>=0.01$, (BT) $=1$, otherwise $(\mathrm{BT})=0$. (J_BT) if firm-years with $\mathrm{N}_{\mathrm{It}} / \mathrm{ASSET}_{\mathrm{t}-1}$ is between zero and 0.01 , (J_BT) $=1$, otherwise J_BT $=0$. (MS) if firm-years with $\mathrm{N}_{\mathrm{It}} / \mathrm{ASSET}_{\mathrm{t}-1}$ is $<0.01$, (MS) $=1$, otherwise $(\mathrm{MS})=0$. (J_MS) if firm-years with $\mathrm{N}_{\mathrm{It}} / \mathrm{ASSET}_{\mathrm{t}-1}$ is between zero and $-0.01,\left(\mathrm{~J} \_\mathrm{MS}\right)=1$, otherwise $\left(\mathrm{J} \_\mathrm{MS}\right)=0$. Accordingly, this study concentrates mainly on meeting or beating the zero earnings as a proxy for earnings benchmarks.

\subsubsection{Research Model}

To test this study's three hypotheses, I used panel data with fixed effect and employed ten Ordinary Least Squares (OLS) models after controlling for industry type, years, and some variables. Based on (Choi et al., 2016; Nagar and Radhakrishan, 2017; Da Silva Roma et al., 2020), I included in this study four control variables. These were: namely, company size (Size); firm performance measured by Return on Assets (ROA); firm risk measured by leverage (Lev); and firm growth measured by Market to Book Ratio (MTB). Table3 presents the proxies of all this study's variables. 
The Relationship between Earnings Benchmarks and Earnings Management .....

Dr/ Amr Nazieh Mahmoud Ezat

\section{Table 3: The variable definitions and their proxies}

\begin{tabular}{|c|c|c|}
\hline Variable & Acronym & Proxy \\
\hline Firm life cycle stages: & FLC & \\
\hline Introduction & IN & $\mathrm{CFO}(-), \mathrm{CFI}(-), \mathrm{CFF}(+)$ \\
\hline Growth & GW & $\mathrm{CFO}(+), \mathrm{CFI}(-), \mathrm{CFF}(+)$ \\
\hline Maturity & MU & $\mathrm{CFO}(+), \mathrm{CFI}(-), \mathrm{CFF}(-)$ \\
\hline Decline & DC & $\begin{array}{l}\mathrm{CFO}(-), \mathrm{CFI}(-), \mathrm{CFF}(-) \\
\text { or } \\
\mathrm{CFO}(+), \mathrm{CFI}(+), \mathrm{CFF}(+) \\
\text { or } \\
\mathrm{CFO}(+), \mathrm{CFI}(+), \mathrm{CFF}(-) \\
\text { or } \\
\mathrm{CFO}(-), \mathrm{CFI}(+), \\
\mathrm{CFF}(+) \text { or } \\
\mathrm{CFO}(-), \mathrm{CFI}(+), \mathrm{CFF}(-)\end{array}$ \\
\hline Accrual Earnings management & AEM & $\begin{array}{l}\varepsilon_{i t} \text { of performance- } \\
\text { adjusted modified jones } \\
\text { model }\end{array}$ \\
\hline Real earnings management & REM & $\begin{array}{l}\text { ABCFO + ABPROD - } \\
\text { ABDISX }\end{array}$ \\
\hline Earnings benchmarks: & EB & Dummy variable equal to \\
\hline Beat & BT & $\begin{array}{l}1 \text { if firm-years with NIt } \\
\text { /ASSETt- } 1 \text { is }>=0.01,0 \\
\text { otherwise }\end{array}$ \\
\hline Just Beat & J_BT & $\begin{array}{l}\text { Dummy variable equal to } \\
1 \text { if firm-years with NIt } \\
\text { /ASSETt- } 1 \text { is between } \\
\text { zero and } 0.01,0 \text { otherwise }\end{array}$ \\
\hline Miss & MS & $\begin{array}{l}\text { Dummy variable equal to } \\
1 \text { if firm-years with NIt } \\
\text { /ASSETt- } 1 \text { is }<0.01,0 \\
\text { otherwise }\end{array}$ \\
\hline
\end{tabular}


The Relationship between Earnings Benchmarks and Earnings Management .....

Dr/ Amr Nazieh Mahmoud Ezat

\begin{tabular}{|l|l|l|}
\hline Just Miss & J_MS & $\begin{array}{l}\text { Dummy variable equal to } \\
1 \text { if firm-years with NIt } \\
\text { /ASSETt-1 is is between } \\
\text { zero and }-0.01,0 \text { otherwise }\end{array}$ \\
\hline Size & size & $\begin{array}{l}\text { Natural logarithm of total } \\
\text { assets }\end{array}$ \\
\hline Performance & ROA & $\begin{array}{l}\text { Net income deflated by } \\
\text { total assets }\end{array}$ \\
\hline Risk & Lev & $\begin{array}{l}\text { Total liabilities deflated } \\
\text { by total equity }\end{array}$ \\
\hline Firm Growth & MTB & Market /Book ratio \\
\hline
\end{tabular}

Consequently, the main research models presented as follows:

To test the first hypothesis, the following four models are employed:

$J_{-} B T=\beta_{0}+\beta_{1} I N+\beta_{2} G W+\beta_{3} M U+\beta_{4} D C+\beta_{5}$ Size $+\beta_{6} L e v+$ $\beta_{7} R O A+\beta_{8} M T B+$

$\beta_{9}$ Type $+\beta_{10}$ year $+\boldsymbol{\varepsilon}$

Where: J_BT denotes to (Just beat) earnings benchmark which reflects the small profit; IN denotes to the introduction phase; $\mathrm{GW}$ denotes to the growth phase; MU denotes to the maturity phase; DC denotes to the decline phase; Size is the company size; Lev is the leverage, ROA is the return on asset ratio, MTB is the market to book ratio, and Type is the industry type.

$B T=\beta_{0}+\beta_{1} I N+\beta_{2} G W+\beta_{3} M U+\beta_{4} D C+\beta_{5}$ Size $+\beta_{6} L e v+$ $\beta_{7}$ ROA $+\beta_{8} M T B+\beta_{9}$ Type $+\beta_{10}$ year $+\varepsilon$ 
The Relationship between Earnings Benchmarks and Earnings Management .....

Dr/ Amr Nazieh Mahmoud Ezat

Where: BT denotes to (Beat) earnings benchmark which reflects the large profit.

$$
\begin{aligned}
& J \_M S=\beta_{0}+\beta_{1} I N+\beta_{2} G W+\beta_{3} M U+\beta_{4} D C+\beta_{5} \text { Size }+\beta_{6} L e v \\
& +\beta_{7} R O A+\beta_{8} M T B+\beta_{9} \text { Type }+\beta_{10} \text { year }+\boldsymbol{\varepsilon}
\end{aligned}
$$

Where: J_MS denotes to (Just miss) earnings benchmark which reflects the small losses.

$M S=\beta_{0}+\beta_{1} I N+\beta_{2} G W+\beta_{3} M U+\beta_{4} D C+\beta_{5}$ Size $+\beta_{6} L e v+$

$\beta_{7} R O A+\beta_{8} M T B+\beta_{9}$ Type $+\beta_{10}$ year $+\varepsilon$

Where: MS denotes to (Miss) earnings benchmark which reflects the large losses>

In addition, the following two models are used to examine the impact of firm's life cycle on earnings management in the Egyptian context denoting to the second hypothesis:

$$
\begin{aligned}
& A A E M=\beta_{0}+\beta_{1} I N+\beta_{2} G W+\beta_{3} M U+\beta_{4} D C+\beta_{5} \text { Size }+\beta_{6} L e v \\
& +\beta_{7} R O A+\beta_{8} M T B+\beta_{9} \text { Type }+\beta_{10} \text { year }+\mathbf{\varepsilon}
\end{aligned}
$$

Where: AAEM is the abnormal accrual earnings management. $A R E M=\beta_{0}+\beta_{1} I N+\beta_{2} G W+\beta_{3} M U+\beta_{4} D C+\beta_{5}$ Size $+\beta_{6}$ Lev $+\beta_{7} R O A+\beta_{8} M T B+\beta_{9}$ Type $+\beta_{10}$ year $+\varepsilon$

Where: AREM is the abnormal real earnings management.

Finally, to test the third hypothesis. The study investigates earnings management tools on earnings benchmarks across the stages of life cycle, the following four models are run:

$$
\begin{aligned}
& J \_B T=\beta_{0}+\beta_{1} I N+\beta_{2} G W+\beta_{3} M U+\beta_{4} D C+\beta_{5} A E M+\beta_{6} \\
& A E M \times I N+\beta_{7} A E M \times G W+\beta_{8} A E M \times M U+\beta_{9} A E M \times C+\beta_{10} \\
& \text { Size }+\beta_{11} L e v+\beta_{12} R O A+\beta_{13} M T B+\beta_{14} T y p e+\beta_{15} \text { year }+\mathbf{\varepsilon}(\mathbf{7 a )} \\
& \hline \text { إr }
\end{aligned}
$$


The Relationship between Earnings Benchmarks and Earnings Management .....

Dr/ Amr Nazieh Mahmoud Ezat

$J_{-} B T=\beta_{0}+\beta_{1} I N+\beta_{2} G W+\beta_{3} M U+\beta_{4} D C+\beta_{5} R E M+\beta_{6}$ $R E M \times I N+\beta_{7} R E M \times G W+\beta_{8} R E M \times M U+\beta_{9} R E M \times D C+\beta_{10}$ Size $+\beta_{11}$ Lev $+\beta_{12}$ ROA $+\beta_{13}$ MTB $+\beta_{14}$ Type $+\beta_{15}$ year $+\mathbf{\varepsilon}$ (7b) $B T=\beta_{0}+\beta_{1} I N+\beta_{2} G W+\beta_{3} M U+\beta_{4} D C+\beta_{5} A E M+\beta_{6} A E M \times$ $I N+\beta_{7} A E M \times G W+\beta_{8} A E M \times M U+\beta_{9} A E M \times C+\beta_{10}$ Size + $\beta_{11}$ Lev $+\beta_{12}$ ROA $+\beta_{13} M T B+\beta_{14}$ Type $+\beta_{15}$ year $+\varepsilon$ $B T=\beta_{0}+\beta_{1} I N+\beta_{2} G W+\beta_{3} M U+\beta_{4} D C+\beta_{5} R E M+\beta_{6} R E M \times$ $I N+\beta_{7} R E M \times G W+\beta_{8} R E M \times M U+\beta_{9} R E M \times D C+\beta_{10}$ Size + $\beta_{11}$ Lev $+\beta_{12} R O A+\beta_{13} M T B+\beta_{14}$ Type $+\beta_{15}$ year $+\varepsilon$

$J \_M S=\beta_{0}+\beta_{1} I N+\beta_{2} G W+\beta_{3} M U+\beta_{4} D C+\beta_{5} A E M+\beta_{6}$ $A E M \times I N+\beta_{7} A E M \times G W+\beta_{8} A E M \times M U+\beta_{9} A E M \times C+\beta_{10}$ Size $+\beta_{11}$ Lev $+\beta_{12}$ ROA $+\beta_{13}$ MTB $+\beta_{14}$ Type $+\beta_{15}$ year $+\varepsilon$ (9a) $J \_M S=\beta_{0}+\beta_{1} I N+\beta_{2} G W+\beta_{3} M U+\beta_{4} D C+\beta_{5} R E M+\beta_{6}$ $R E M \times I N+\beta_{7} R E M \times G W+\beta_{8} R E M \times M U+\beta_{9} R E M \times D C+\beta_{10}$ Size $+\beta_{11}$ Lev $+\beta_{12} R O A+\beta_{13}$ MTB $+\beta_{14}$ Type $+\beta_{15}$ year $+\varepsilon \mathbf{\varepsilon}(\mathbf{9 b})$ $M S=\beta_{0}+\beta_{1} I N+\beta_{2} G W+\beta_{3} M U+\beta_{4} D C+\beta_{5} A E M+\beta_{6} A E M \times$ $I N+\beta_{7} A E M \times G W+\beta_{8} A E M \times M U+\beta_{9} A E M \times C+\beta_{10}$ Size + $\beta_{11}$ Lev $+\beta_{12}$ ROA $+\beta_{13} M T B+\beta_{14}$ Type $+\beta_{15}$ year $+\varepsilon$ $M S=\beta_{0}+\beta_{1} I N+\beta_{2} G W+\beta_{3} M U+\beta_{4} D C+\beta_{5} R E M+\beta_{6} R E M \times$ $I N+\beta_{7} R E M \times G W+\beta_{8} R E M \times M U+\beta_{9} R E M \times D C+\beta_{10}$ Size + $\beta_{11}$ Lev $+\beta_{12} R O A+\beta_{13} M T B+\beta_{14}$ Type $+\beta_{15}$ year $+\varepsilon$

(10b)

\section{Results and Discussion}

4.1 Descriptive and Univariant Analysis

Table 4 presents the characteristics of life cycle descriptors for the Egyptian firms. 
The Relationship between Earnings Benchmarks and Earnings Management .....

Dr/ Amr Nazieh Mahmoud Ezat

Table 4: The characteristics of life cycle descriptors

\begin{tabular}{|l|l|l|l|l|}
\hline \multirow{2}{*}{ Cash flow } & \multicolumn{4}{|c|}{ Stages of firm life cycle } \\
\cline { 2 - 5 } & Introduction & Growth & Mature & Decline \\
\hline Operating & - & + & + & - \\
\hline Investing & - & - & - & + \\
\hline Financing & + & + & - & $(+/-)$ \\
\hline N & 81 & 78 & 235 & 254 \\
\hline
\end{tabular}

Further, Table 5 indicates the descriptive characteristics of each firm's life cycle. Most Egyptian firms (75\%) are in the maturity and decline stage and of these $39 \%$ are in the decline stage. The lowest number of Egyptian firms (12\%) are in the growth stage. Most Egyptian firms are in the latest stages which indicates the massive competition in the Egyptian market and the limitation of growth opportunities for these firms due to the acquired small market share.

Table 5: descriptive characteristics of each stage of Egyptian firm's life

\begin{tabular}{|l|l|l|l|l|l|l|}
\hline Variables & $\mathrm{N}$ & Mean & SD & Median & $\begin{array}{l}\text { Q1 } \\
25 \%\end{array}$ & $\begin{array}{l}\text { Q3 } \\
75 \%\end{array}$ \\
\hline Introduction & 81 & 0.13 & 0.331 & 0 & 0 & 0 \\
\hline Growth & 78 & 0.12 & 0.326 & 0 & 0 & 0 \\
\hline Mature & 235 & 0.36 & 0.481 & 0 & 0 & 1 \\
\hline Decline & 254 & 0.39 & 0.488 & 0 & 0 & 1 \\
\hline $\begin{array}{l}\text { Total } \\
\text { observation }\end{array}$ & 648 & & & & & \\
\hline
\end{tabular}

In addition, Table 6 demonstrates the sampled Egyptian firms' characteristics in each stage of the life cycle. The frequency of 
The Relationship between Earnings Benchmarks and Earnings Management .....

Dr/ Amr Nazieh Mahmoud Ezat

Egyptian firms, related to earnings benchmark, shows that most Egyptian firms report profits across the stages of their life cycles. In Table 6, when compared to the other life cycle stages, this pattern is more noticeable in the maturity stage. For each earnings benchmark, there are variations across the Egyptian firms' life cycles. The mean of firms that just beat (earnings bins 0.00 to 0.01 ) in all stages is higher than those that just miss (earnings bins -0.01 to 0.00 ). The mean of firms that just beat in introduction (0.07), growth (0.05), mature (0.05), and decline (0.12) respectively are higher than those that just miss in introduction (0.02), growth (0.01), mature (0.02), and decline (0.03) respectively. In the decline stage and in order to hide their potential financial distress and to keep their debt covenants and to ensure their survival, firms are more interested in just beat the earnings when compared to those firms in other stages (Bartov et al., 2002; Nagar and Sen, 2017). In addition, firms that beat (earnings bins $>0.01$ ) in all stages are higher than those that miss (earnings bins $<-0.01$ ). The mean of firms that beat in introduction (0.57), growth $(0.76)$, mature $(0.86)$, and decline (0.61) respectively are higher than those that miss in introduction (0.33), growth (0.18), mature (0.08), and decline (0.24) respectively. In the maturity stage and when compared to other stages, firms report the highest mean of beat the earnings. This is done to attain their investors' expectations about the high level of profits and to protect their reputations and to be seen to be trustworthy in the market (Graham et al., 2005) 
The Relationship between Earnings Benchmarks and Earnings Management .....

Dr/ Amr Nazieh Mahmoud Ezat

As regards earnings management tools, Table 6 illustrates that in all stages of their life cycles, Egyptian firms have a slight preference to perform AER rather than REM for. On average, Egyptian firms are more likely to perform both AER (0.765) and REM (-0.946) tools in introduction stage than in any other stages. Moreover, Table 6 reports the rest of study's control variables. On the one hand, in the Introduction stage, Egyptian firms are characterized by large size (9.254), high risk measured by lev (0.710) and high market to book value (3.483). On the other hand, in the maturity stage, Egyptian firms are characterized by high performance as measured by ROA (0.536).

Table 6: descriptive statistics for study's variables in each stage of Egyptian firm's life cycle

\begin{tabular}{|c|c|c|c|c|c|c|}
\hline Variables & No. & Mean & SD & Median & Q1 25\% & Q3 75\% \\
\hline \multicolumn{7}{|l|}{ J_BT } \\
\hline All stages & 51 & 0.08 & 0.270 & 0 & 0 & 0 \\
\hline Introduction & 6 & 0.07 & 0.264 & 0 & 0 & 0 \\
\hline Growth & 4 & 0.05 & 0.222 & 0 & 0 & 0 \\
\hline Mature & 11 & 0.05 & 0.212 & 0 & 0 & 0 \\
\hline Decline & 30 & 0.12 & 0.323 & 0 & 0 & 0 \\
\hline \multicolumn{7}{|l|}{ BT } \\
\hline All stages & 461 & 0.71 & 0.453 & 1 & 0 & 1 \\
\hline Introduction & 46 & 0.57 & 0.498 & 1 & 0 & 1 \\
\hline Growth & 59 & 0.76 & 0.423 & 1 & 0 & 1 \\
\hline Mature & 201 & 0.86 & 0.353 & 1 & 1 & 1 \\
\hline Decline & 155 & 0.61 & 0.489 & 1 & 0 & 1 \\
\hline \multicolumn{7}{|l|}{ J_MS } \\
\hline $\begin{array}{l}\text { All stages } \\
\text { nntrotion }\end{array}$ & 14 & 0.02 & 0.146 & 0 & 0 & 0 \\
\hline Introduction & 2 & 0.02 & 0.156 & 0 & 0 & 0 \\
\hline
\end{tabular}


The Relationship between Earnings Benchmarks and Earnings Management .....

Dr/ Amr Nazieh Mahmoud Ezat

\begin{tabular}{|c|c|c|c|c|c|c|}
\hline $\begin{array}{l}\text { Growth } \\
\text { Mature } \\
\text { Decline }\end{array}$ & $\begin{array}{l}1 \\
4 \\
7\end{array}$ & $\begin{array}{l}0.01 \\
0.02 \\
0.03\end{array}$ & $\begin{array}{l}0.113 \\
0.130 \\
0.164\end{array}$ & $\begin{array}{l}0 \\
0 \\
0\end{array}$ & $\begin{array}{l}0 \\
0 \\
0\end{array}$ & $\begin{array}{l}0 \\
0 \\
0\end{array}$ \\
\hline $\begin{array}{c}\text { MS } \\
\text { All stages } \\
\text { Introduction } \\
\text { Growth } \\
\text { Mature } \\
\text { Decline }\end{array}$ & $\begin{array}{l}122 \\
27 \\
14 \\
19 \\
62\end{array}$ & $\begin{array}{l}0.19 \\
0.756 \\
0.18 \\
0.08 \\
0.24\end{array}$ & $\begin{array}{l}0.391 \\
0.474 \\
0.386 \\
0.273 \\
0.430\end{array}$ & $\begin{array}{l}0 \\
0 \\
0 \\
0 \\
0\end{array}$ & $\begin{array}{l}0 \\
0 \\
0 \\
0 \\
0\end{array}$ & $\begin{array}{l}0 \\
1 \\
0 \\
0 \\
0\end{array}$ \\
\hline $\begin{array}{c}\text { AEM } \\
\text { All stages } \\
\text { Introduction } \\
\text { Growth } \\
\text { Mature } \\
\text { Decline }\end{array}$ & $\begin{array}{l}648 \\
81 \\
78 \\
235 \\
254 \\
\end{array}$ & $\begin{array}{l}0.569 \\
0.765 \\
0.373 \\
0.529 \\
0.600 \\
\end{array}$ & $\begin{array}{l}0.830 \\
0.772 \\
0.403 \\
1.010 \\
0.742 \\
\end{array}$ & $\begin{array}{l}0.348 \\
0.577 \\
0.240 \\
0.375 \\
0.332 \\
\end{array}$ & $\begin{array}{l}0.157 \\
0.181 \\
0.110 \\
0.192 \\
0.156 \\
\end{array}$ & $\begin{array}{l}0.412 \\
0.932 \\
0.539 \\
0.673 \\
0.398 \\
\end{array}$ \\
\hline $\begin{array}{c}\text { REM } \\
\text { All stages } \\
\text { Introduction } \\
\text { Growth } \\
\text { Mature } \\
\text { Decline }\end{array}$ & $\begin{array}{l}648 \\
81 \\
78 \\
235 \\
254 \\
\end{array}$ & $\begin{array}{l}-0.008 \\
-0.946 \\
0.120 \\
0.504 \\
-0.210\end{array}$ & $\begin{array}{l}1.858 \\
0.841 \\
1.295 \\
1.713 \\
1.728\end{array}$ & $\begin{array}{l}0.038 \\
-0.716 \\
-0.114 \\
0.246 \\
-0.332\end{array}$ & $\begin{array}{l}-0.508 \\
-1.155 \\
-0.308 \\
-0.055 \\
-0.676\end{array}$ & $\begin{array}{l}0.513 \\
-0.492 \\
0.229 \\
0.713 \\
0.167\end{array}$ \\
\hline $\begin{array}{c}\text { Size } \\
\text { All stages } \\
\text { Introduction } \\
\text { Growth } \\
\text { Mature } \\
\text { Decline }\end{array}$ & $\begin{array}{l}648 \\
81 \\
78 \\
235 \\
254 \\
\end{array}$ & $\begin{array}{l}8.985 \\
9.024 \\
9.254 \\
9.118 \\
8.766\end{array}$ & $\begin{array}{l}0.782 \\
0.707 \\
0.842 \\
0.803 \\
0.712\end{array}$ & $\begin{array}{l}8.936 \\
9.047 \\
9.155 \\
9.194 \\
8.757\end{array}$ & $\begin{array}{l}8.460 \\
8.420 \\
8.658 \\
8.646 \\
8.168 \\
\end{array}$ & $\begin{array}{l}9.454 \\
9.525 \\
9.801 \\
9.621 \\
9.214\end{array}$ \\
\hline $\begin{array}{c}\text { Lev } \\
\text { All stages } \\
\text { Introduction } \\
\text { Growth } \\
\text { Mature } \\
\text { Decline }\end{array}$ & $\begin{array}{l}648 \\
81 \\
78 \\
235 \\
254 \\
\end{array}$ & $\begin{array}{l}-1.524 \\
0.710 \\
0.492 \\
-5.113 \\
0.465\end{array}$ & $\begin{array}{l}36.395 \\
0.434 \\
0.249 \\
60.348 \\
0.304\end{array}$ & $\begin{array}{l}0.473 \\
0.620 \\
0.483 \\
0.432 \\
0.447 \\
\end{array}$ & $\begin{array}{l}0.291 \\
0.454 \\
0.326 \\
0.272 \\
0.268 \\
\end{array}$ & $\begin{array}{l}0.654 \\
0.851 \\
0.690 \\
0.611 \\
0.643 \\
\end{array}$ \\
\hline
\end{tabular}


The Relationship between Earnings Benchmarks and Earnings Management .....

Dr/ Amr Nazieh Mahmoud Ezat

\begin{tabular}{|c|c|c|c|c|c|c|}
\hline \multicolumn{7}{|l|}{ ROA } \\
\hline All stages & 648 & 0.221 & 3.981 & 0.043 & 0.004 & 0.108 \\
\hline Introduction & 81 & 0.008 & 0.152 & 0.022 & -0.025 & 0.083 \\
\hline Growth & 78 & 0.052 & 0.092 & 0.040 & 0.011 & 0.085 \\
\hline Mature & 235 & 0.536 & 6.603 & 0.075 & 0.026 & 0.146 \\
\hline Decline & 254 & 0.048 & 0.197 & 0.028 & -0.009 & 0.088 \\
\hline \multicolumn{7}{|l|}{ MTB } \\
\hline All stages & 648 & 1.916 & 5.767 & 1.017 & 0.30 & 1.771 \\
\hline Introduction & 81 & 3.483 & 7.928 & 0.949 & 0.573 & 2.373 \\
\hline Growth & 78 & 0.620 & 5.821 & 1.054 & 0.647 & 1.827 \\
\hline Mature & 235 & 2.284 & 6.819 & 1.091 & 0.609 & 2.194 \\
\hline Decline & 254 & 1.473 & 3.199 & 0.961 & 0.642 & 1.550 \\
\hline
\end{tabular}

Table 7 presents the correlation matrix for this study's variables. All stages of the firm's life cycle are correlated with the earnings benchmarks expected at the growth stage. Similarly, other than the exception of the growth stage, both AE and REM tools are correlated with the stages of a firm's life cycle (Choi et al., 2016, Da Silva Roma et al., 2020). These findings demonstrate that Egyptian firms may manipulate their earnings in the early and late stages. In addition, variables like size, leverage, Return on Assets (ROA) and MTB are consistent with the findings of previous studies contained in life cycle literature. Introduction firms are correlated with high market to book value (Da Silva Roma et al., 2020); growth firms are correlated with higher MTB and with smaller size (Choi et al., 2016). mature firms are correlated only with the larger size (Da Silva Roma et al., 2020); and, finally, decline firms are correlated only with smaller size (Da Silva Roma et al., 2020). 
The Relationship between Earnings Benchmarks and Earnings Management .....

Dr/ Amr Nazieh Mahmoud Ezat

Table 7: Pearson coefficient correlation matrix

\begin{tabular}{|l|l|l|l|l|l|l|l|l|l|l|l|l|l|}
\hline & IN & GW & MU & DC & J_BT & BT & J_MS & MS & AEM & REM & Size & Lev & ROA \\
\hline GW & $-.140^{* *}$ & & & & & & & & & & & & \\
\hline MU & $-.285^{* *}$ & $-.279^{* *}$ & & & & & & & & & & & \\
\hline DC & $-.303^{* *}$ & $-.297^{* *}$ & $-.606^{* *}$ & & & & & & & & & & \\
\hline J_BT & -.006 & -.038 & $-.089^{*}$ & $.118^{* *}$ & & & & & & & & & \\
\hline BT & $-.120^{* *}$ & .037 & $.240^{* *}$ & $-.179^{* *}$ & $-.459^{* *}$ & & & & & & & & \\
\hline J_MS & .008 & -.022 & -.024 & .033 & -.043 & $-.233^{* *}$ & & & & & & & \\
\hline MS & $.140^{* *}$ & -.008 & $-.207^{* *}$ & $.115^{* *}$ & $-.141^{* *}$ & $-.756^{* *}$ & -.072 & & & & & & \\
\hline AEM & $.094^{*}$ & $-.087^{*}$ & -.036 & .030 & -.032 & .022 & -.023 & .005 & & & & & \\
\hline REM & $.211^{* *}$ & -.050 & $-.335^{* *}$ & $.220^{* *}$ & -.022 & $-.120^{* *}$ & -.002 & $.157^{* *}$ & -.009 & & & & \\
\hline Size & .019 & $-.127^{* *}$ & $.129^{* *}$ & $-.225^{* *}$ & $-.109^{* *}$ & $.184^{* *}$ & -.052 & $-.119^{* *}$ & .002 & -.048 & & & \\
\hline Lev & .023 & .021 & -.074 & .044 & .016 & -.037 & .008 & .029 & .009 & .012 & $.283^{* *}$ & & \\
\hline ROA & -.020 & -.016 & .060 & -.035 & -.016 & .045 & -.008 & -.038 & -.004 & $-.079^{*}$ & -.043 & .001 & \\
\hline MTB & $.103^{* *}$ & $.083^{*}$ & .048 & -.062 & .004 & -.011 & -.021 & .018 & .016 & -.018 & .000 & .006 & .000 \\
\hline
\end{tabular}

No serious multicollinearity among the independent variables.

\subsection{Multivariate Analysis}

For multivariate analysis, I ran in this study ten panel data OLS models that considered the fixed effects in all models to estimate the regression coefficients.

To test hypothesis 1, I used four main models to test the impact of Egyptian firms' life cycles on each earnings benchmark. Table 8 presents the results of the four models (model 1 for J_BT, model 2 for BT, model 3 for J_MS, and model 4 for $\mathrm{MS}$ ). The adjusted $\mathrm{R}^{2}$ is $3.2 \%, 19 \%, 0.9 \%$, and $14.6 \%$ for the four models respectively. At least one of each life 
The Relationship between Earnings Benchmarks and Earnings Management .....

Dr/ Amr Nazieh Mahmoud Ezat

cycle stage impacts on one of the earning benchmarks.

At the introduction stage, Egyptian firms are more likely to miss the earnings target. Introduction stage is associated positively and significantly $(\mathrm{p}<0.1)$ with the miss earnings benchmark. One reason for that is the high expected spending rate related to the introduction stage. This is due to the Egyptian firms increasing their investment on innovation and market branding activities to strengthen their existence in the market. Further, cash flow from operating is negative at this stage. Consequently, high spending rates and negative operating cash flow may lead these firms to miss their earnings. Introductionfirms do not hold cash to meet their financial requirements (Al zoubi, 2019) and accelerate their spending rate. This may affect indirectly the profits obtained at this stage and, hence, these firms miss their earnings targets.

As regards the growth stage, Egyptian firms have a positive and significant statistical $(\mathrm{p}<0.05)$ relationship with the beat the earnings benchmark and have more incentive to do so. There are many reasons to explain this behavior. First, there is the market's positive reaction when firms beat their earnings as reflected in increased share returns and signaled by these firms' high performance (Collins and Kothari, 1989; Skinner and Sloan, 2002; Ertimur et al.,2003). Second, there is the need for external finance to expand the Egyptian firms' growth opportunities. This may be achieved when they beat their earnings benchmarks by 
The Relationship between Earnings Benchmarks and Earnings Management .....

Dr/ Amr Nazieh Mahmoud Ezat

sending positive signals about their strong financial positions and which may increase the potential to obtain finance from capital providers. This result is consistent with Choi et al.'s (2016) findings emphasizing that growth firms tend to meet or beat their earnings benchmarks.

With respect to the maturity stage, Table 6 shows that there is positive and significant association between such Egyptian firms and their beating the earnings benchmarks ( $p<0.01)$. This is due to such Egyptian firms having high incentives of to beat their earning benchmarks that may be attributed to these firms' unique characteristics. Such Egyptian firms have great experience and have achieved high levels of leadership and performance. Consequently, these increase the pressure on them to beat the earnings benchmarks to reflect these characteristics and reinforce their reputations and positions in the market. This result is in line with Graham et al.'s (2005) finding (in Nagar and Radhakrishan, 2017). They argued that, by meeting their earnings benchmarks, such firms' managers were more likely to increases their reputations.

Finally, in the decline stage, there is a positive positively and statistically significant $(\mathrm{p}<0.01)$ association between such Egyptian firms and missing their earning benchmarks. In this stage, such firms suffer from the severe competition which leads to low levels of sales and poor profits and which may subject these firms to financial distress. Consequently, decline- stage 
The Relationship between Earnings Benchmarks and Earnings Management .....

Dr/ Amr Nazieh Mahmoud Ezat

Egyptian firms are more likely to miss their earnings benchmarks. Habib and Hasan, (2017) indicated that risk rate is high during the decline stage which has a negative effect on such firms' future performance and this may make them miss their earnings targets.

Accordingly, each stage of a listed Egyptian firm's life cycle impacts on its earning benchmark. This is explained by the prospect theory premises and, therefore, hypothesis 1 is accepted. As regards the control variable, Table 8 reports that larger Egyptian firms with less debt are more likely to beat or just beat their earning benchmarks.

Table 8: Regression results of the association between firm's life cycle and earnings benchmarks

\begin{tabular}{|c|c|c|c|c|}
\hline & $\begin{array}{c}\text { Model (1) } \\
\text { J_Bt }\end{array}$ & $\begin{array}{c}\text { Model (2) } \\
\text { BT }\end{array}$ & $\begin{array}{c}\text { Model (3) } \\
\text { J_MS }\end{array}$ & $\begin{array}{c}\text { Model (4) } \\
\text { MS }\end{array}$ \\
\hline Constant & $\begin{array}{l}\mathbf{0 . 3 8 6} \text { **** } \\
(\mathbf{2 . 8 3 3 )}\end{array}$ & $\begin{array}{l}-0.318 \\
(-1.514)\end{array}$ & $\begin{array}{l}0.110 \\
(1.460)\end{array}$ & $\begin{array}{l}0.821 * * * * \\
(4.417)\end{array}$ \\
\hline IN & $\begin{array}{l}-0.020 \\
(-0.543)\end{array}$ & $\begin{array}{l}-0.067 \\
(-1.211)\end{array}$ & $\begin{array}{l}0.005 \\
(0.262)\end{array}$ & $\begin{array}{l}\text { 0.081* } \\
(1.657)\end{array}$ \\
\hline GW & $\begin{array}{l}-0.033 \\
(-0.898)\end{array}$ & $\begin{array}{l}\text { 0.133** } \\
(2.377)\end{array}$ & $\begin{array}{l}-0.013 \\
(-0.650)\end{array}$ & $\begin{array}{l}-0.087 \\
(-1.159)\end{array}$ \\
\hline $\mathrm{MU}$ & $\begin{array}{l}-0.037 \\
(-1.381)\end{array}$ & $\begin{array}{l}0.232^{* * * *} \\
(5.683)\end{array}$ & $\begin{array}{l}-0.011 \\
(-0.777)\end{array}$ & $\begin{array}{l}-0.105 \\
(-1.748)\end{array}$ \\
\hline DC & $\begin{array}{l}0.063 \\
(1.560)\end{array}$ & $\begin{array}{l}0.089 \\
(1.537)\end{array}$ & $\begin{array}{l}0.042 \\
(1.057)\end{array}$ & $\begin{array}{l}\mathbf{0 . 1 8 4} * * * * \\
(5.082)\end{array}$ \\
\hline Size & $\begin{array}{l}0.039 * * \\
(2.494)\end{array}$ & $\begin{array}{l}\mathbf{0 . 1 1 0} \text { ***** } \\
(4.598)\end{array}$ & $\begin{array}{l}-0.009 \\
(-1.046)\end{array}$ & $\begin{array}{l}0.006 \\
(1.193) \\
\end{array}$ \\
\hline Lev & $\begin{array}{l}0.041 \\
(0.988)\end{array}$ & $\begin{array}{l}-0.001 * \\
(-1.689)\end{array}$ & $\begin{array}{l}0.006 \\
(0.335)\end{array}$ & $\begin{array}{l}0.034 \\
(1.044)\end{array}$ \\
\hline
\end{tabular}


The Relationship between Earnings Benchmarks and Earnings Management .....

Dr/ Amr Nazieh Mahmoud Ezat

\begin{tabular}{|l|l|l|l|l|}
\hline ROA & $\begin{array}{l}-0.005 \\
(-0.134)\end{array}$ & $\begin{array}{l}0.002 \\
(0.377)\end{array}$ & $\begin{array}{l}-0.007 \\
(-0.048)\end{array}$ & $\begin{array}{l}-0.001 \\
(-0.308)\end{array}$ \\
\hline MTB & $\begin{array}{l}0.001 \\
(0.553)\end{array}$ & $\begin{array}{l}-0.004 \\
(-1.209)\end{array}$ & $\begin{array}{l}-0.001 \\
(-0.698)\end{array}$ & $\begin{array}{l}0.003 \\
(1.240)\end{array}$ \\
\hline \multicolumn{1}{|c|}{ Other statistics } & & & & \\
\hline Industry Fixed effect & Yes & Yes & Yes & Yes \\
\hline Year Fixed effect & Yes & Yes & Yes & Yes \\
\hline F-Ratio (sig.) & $\mathbf{1 . 8 4 1} * * *$ & $\mathbf{7 . 0 8 2} * * *$ & $\mathbf{0 . 7 6 9}$ & $\mathbf{5 . 3 9 4} * * *$ \\
\hline Adj. R $^{2}$ & $\mathbf{0 . 0 3 2}$ & $\mathbf{0 . 1 9 1}$ & $\mathbf{0 . 0 0 9}$ & $\mathbf{0 . 1 4 6}$ \\
\hline Max. VIF & $\mathbf{1 . 7 1 2}$ & $\mathbf{1 . 7 1 2}$ & $\mathbf{1 . 7 1 2}$ & $\mathbf{1 . 7 1 2}$ \\
\hline Min. Tolerance & $\mathbf{0 . 5 8 4}$ & $\mathbf{0 . 5 8 4}$ & $\mathbf{0 . 5 8 4}$ & $\mathbf{0 . 5 8 4}$ \\
\hline Number of observations & $\mathbf{6 4 8}$ & $\mathbf{6 4 8}$ & $\mathbf{6 4 8}$ & $\mathbf{6 4 8}$ \\
\hline
\end{tabular}

Note: The parameters in model (1) are estimated based on the following model:

$$
J_{-} \text {BT }=\beta_{0}+\beta_{1} \text { IN }+\beta_{2} G W+\beta_{3} \mathrm{MU}+\beta_{4} \mathrm{DC}+\beta_{5} \text { Size }+
$$

$\beta_{6}$ Lev $+\beta_{7}$ ROA $+\beta_{8}$ MTB $+\beta_{9}$ Type $+\beta_{10}$ year $+\varepsilon$

The parameters in model (2) are estimated based on the following model:

$$
\mathrm{BT}=\beta_{0}+\beta_{1} \mathrm{IN}+\beta_{2} \mathrm{GW}+\beta_{3} \mathrm{MU}+\beta_{4} \mathrm{DC}+\beta_{5} \text { Size }+
$$

$\beta_{6}$ Lev $+\beta_{7}$ ROA $+\beta_{8}$ MTB $+\beta_{9}$ Type $+\beta_{10}$ year $+\varepsilon$

The parameters in model (3) are estimated based on the following model:

$$
\mathrm{J}_{-} \mathrm{MS}=\beta_{0}+\beta_{1} \mathrm{IN}+\beta_{2} \mathrm{GW}+\beta_{3} \mathrm{MU}+\beta_{\mathbf{4}} \mathrm{DC}+\beta_{5} \mathrm{Size}+
$$

$\beta_{6} \mathrm{Lev}+\beta_{7}$ ROA $+\beta_{8}$ MTB $+\beta_{9}$ Type $+\beta_{10}$ year $+\varepsilon$

The parameters in model (4) are estimated based on the following model: 
The Relationship between Earnings Benchmarks and Earnings Management .....

Dr/ Amr Nazieh Mahmoud Ezat

\section{$\mathrm{MS}=\boldsymbol{\beta}_{\mathbf{0}}+\boldsymbol{\beta}_{1} \mathrm{IN}+\boldsymbol{\beta}_{2} \mathrm{GW}+\boldsymbol{\beta}_{3} \mathrm{MU}+\boldsymbol{\beta}_{\mathbf{4}} \mathrm{DC}+\boldsymbol{\beta}_{5}$ Size + $\beta_{6}$ Lev $+\beta_{7}$ ROA $+\beta_{8}$ MTB $+\beta_{9}$ Type $+\beta_{10}$ year $+\varepsilon$ \\ Variables as defined in Table 3.}

* Indicate significance at $10 \%$ level in a two-tailed test, ** Indicate significance at $5 \%$ level in a two-tailed test, *** Indicate significance at $1 \%$ level in a two-tailed test.

t-statistics are shown in parentheses.

To test hypothesis 2, I used AEM and REM as two tools of earnings management along with some control variables on the stages of the firm's life cycle. Table 9 presents the results of the association between Egyptian firms' life cycles and earnings management. The adjusted R2 is $1.7 \%$ and $15.4 \%$ for both AEM and REM models respectively. These results are comparable to Hussain et al.'s (2020) findings. The multivariate results indicate that Egyptian firms' life cycles impact on both measures of earnings management.

In the introduction stage, Egyptian firms are more likely to use AEM than REM to manage their earnings. This study's findings show that, for such firms, AEM has a positive and statistically significant $(p<0.05)$ relationship. This finding suggests that, because of the lack of the internal financial resources, the uncertainty of future profits and the negative operating cash flows, such firms need to depict their future growth with optimal situations and provide good signals to their shareholders and lenders to obtain the required finance from external sources. 
The Relationship between Earnings Benchmarks and Earnings Management .....

Dr/ Amr Nazieh Mahmoud Ezat

Therefore, the managers of such firms have more incentives to manage their firms' earnings by using discretion in reported numbers to present the improvements in earnings. (Hasan et al., 2017; Da Silva Roma et al., 2020). This finding is consistent with Krishnan et al.'s (2018) finding since they demonstrated that, at this stage, there is a higher amount of accrual and, hence, the managers are motivated to manipulate their firms' earnings. Further, Hussain et al., (2020) report some factors that increase the incentives of such managers to engage in earnings management tools. These are such as" low profitability, higher cost of debt, bankruptcy risk, high uncertainty of $R \& D$ expenditures, accruals and idiosyncratic volatility". Pachariyanon, (2014) and Da Silva Roma et al. (2020) studies have produced similar results.

As at the introduction -stage, AEM reports a significant association $(\mathrm{p}<0.05)$ with growth- stage Egyptian firms but following a different direction. Such firms are less likely to engage in earnings management practices and are characterized by considerable high volumes of sales, high profit ratios, high market share, less asymmetric information, higher internal cash flow generation, high analyst coverage, lower demand of external financing and high internal control mechanism. In turn, internal control mechanisms restrict these managers' desires to manipulate earnings to protect their firms' reputation in the market and to obtain the required finance for rapid expansion (Krishnan et al., 
The Relationship between Earnings Benchmarks and Earnings Management .....

Dr/ Amr Nazieh Mahmoud Ezat

2018; Habib and Hasan 2019; Akbar et al., 2019; Hussain et al., 2020). This result is consistence with the findings of Shiue et al. (2012), Pachariyanon (2014). Hribar and Yehuda (2015), Kale and Almeida (2019), and Da Silva Roma et al. (2020).

With respect to the maturity stage, no empirical evidence supports the association between earnings management behaviors and Egyptian firms. Consequently, such firms may prefer not to manage their earnings due to, firstly, the lower growth opportunities that leads to reduced profits and, second, to the reduced risks and uncertainty of future earnings and cash flow. Together, these diminish the desires of the managers of such firms to manipulate earnings (Krishnan et al., 2018). In addition, such firms are characterized by high stability and profitability and by positive cash flows from operations and high level of reporting quality which help them to obtain low interest loans rather than debt financing (Bulan and Yan 2010; Zadband and Omrani, 2014; Hribar and Yehuda 2015; Hasan and Habib 2017; Hussain et al., 2020). Therefore, these firms are much more concerned at maintaining what they have achieved rather than searching for new growth opportunities. Accordingly, there is no need for such firms' managers to use earnings management tools (Bulan and Yan, 2010; Hasan et al., 2017; Hussain et al., 2020). Hastuti et al., 2017; Hussain et al., 2020; Can, 2020) are reported similar results.

Finally, in the decline stage, Egyptian firms are more likely to 
The Relationship between Earnings Benchmarks and Earnings Management .....

Dr/ Amr Nazieh Mahmoud Ezat

perform REM rather than AER. Table 6 shows that there is a positive and significant $(\mathrm{p}<0.01)$ association between REM and such firms. However, this association is insignificant with AEM. This suggests that managers of such firms prefer to use REM tools opportunistically to reflect a good financial position to their stakeholders and, at the same time, conceal the poor indications of earnings that such firms may suffer in the decline stage (Krishnan et al., 2018; Hussain et al., 2020). In addition, mangers of such firms may have the incentive to perform REM to avoid violations of debt covenants and to report good business performance which their firms are unable to achieve at this stage (Sweeney, 1994; Defond and Jiambalvo, 1994; Chen et al., 2010) This result is consistence with the findings of Hastuti et al. (2017), Can (2020) and Hussain et al. (2020).

Accordingly, excepting the maturity stage, each stage of an Egyptian firm's life cycle impacts on earnings management tools (AEM and REM) . This result is consistence with signaling theory and, hence, \# hypothesis 2 is accepted. All control variables show an insignificant relationship with both earnings' management tools. 
The Relationship between Earnings Benchmarks and Earnings Management .....

Dr/ Amr Nazieh Mahmoud Ezat

Table 9: Regression results of the association between firm's life cycle and earnings management

\begin{tabular}{|c|c|c|}
\hline & $\begin{array}{c}\text { Model (5) } \\
\text { AEM }\end{array}$ & $\begin{array}{c}\text { Model (6) } \\
\text { REM }\end{array}$ \\
\hline Constant & $\begin{array}{l}0.539 \\
(1.278)\end{array}$ & $\begin{array}{l}0.632 * * \\
(2.554)\end{array}$ \\
\hline IN & $\begin{array}{l}0.079 * * \\
(2.029)\end{array}$ & $\begin{array}{l}0.005 \\
(0.081)\end{array}$ \\
\hline GW & $\begin{array}{l}-0.259 * * \\
(-2.312)\end{array}$ & $\begin{array}{l}-0.106 \\
(-1.619)\end{array}$ \\
\hline MU & $\begin{array}{l}-0.111 \\
(-1.365)\end{array}$ & $\begin{array}{l}-0.053 \\
(-1.104)\end{array}$ \\
\hline $\mathrm{DC}$ & $\begin{array}{l}0.051 \\
(1.293)\end{array}$ & $\begin{array}{l}0.160 * * \\
(2.765)\end{array}$ \\
\hline Size & $\begin{array}{l}0.006 \\
(1.227)\end{array}$ & $\begin{array}{l}-0.036 \\
(-1.282)\end{array}$ \\
\hline Lev & $\begin{array}{l}0.002 \\
(0.054)\end{array}$ & $\begin{array}{l}0.020 \\
(0.471)\end{array}$ \\
\hline ROA & $\begin{array}{l}-0.007 \\
(-0.009)\end{array}$ & $\begin{array}{l}0.002 \\
(0.369)\end{array}$ \\
\hline MTB & $\begin{array}{l}0.009 \\
(1.578)\end{array}$ & $\begin{array}{l}0.002 \\
(0.524)\end{array}$ \\
\hline \multicolumn{3}{|l|}{ Other statistics } \\
\hline Industry Fixed effect & Yes & Yes \\
\hline Year Fixed effect & Yes & Yes \\
\hline F-Ratio (sig.) & 1.473* & $1.591 * *$ \\
\hline Adj. $R^{2}$ & 0.017 & 0.022 \\
\hline
\end{tabular}


The Relationship between Earnings Benchmarks and Earnings Management .....

Dr/ Amr Nazieh Mahmoud Ezat

\begin{tabular}{|l|l|l|}
\hline Max. VIF & $\mathbf{1 . 6 0 3}$ & $\mathbf{1 . 7 1 2}$ \\
\hline Min. Tolerance & $\mathbf{0 . 6 2 4}$ & $\mathbf{0 . 5 8 4}$ \\
\hline Number of observations & $\mathbf{6 4 8}$ & $\mathbf{6 4 8}$ \\
\hline
\end{tabular}

Note: The parameters in model (5) are estimated based on the following model:

$\mathrm{AAEM}=\boldsymbol{\beta O}+\boldsymbol{\beta}_{1} \mathrm{IN}+\beta_{2} \mathrm{GW}+\beta_{3} \mathrm{MU}+\beta_{4} \mathrm{DC}+\beta_{5} \mathrm{Size}+$ $\beta_{6}$ Lev $+\beta_{7}$ ROA $+\beta_{8}$ MTB $+\beta_{9}$ Type $+\beta_{10}$ year $+\varepsilon$

The parameters in model (6) are estimated based on the following model:

$\mathrm{AREM}=\beta 0+\beta_{1} \mathrm{IN}+\beta_{2} \mathrm{GW}+\beta_{3} \mathrm{MU}+\beta_{4} \mathrm{DC}+\beta_{5} \mathrm{Size}+$ $\beta_{6}$ Lev $+\beta_{7}$ ROA $+\beta_{8}$ MTB $+\beta_{9}$ Type $+\beta_{10}$ year $+\varepsilon$

Variables as defined in Table 3.

* Indicate significance at $\mathbf{1 0 \%}$ level in a two-tailed test, ** Indicate significance at $5 \%$ level in a two-tailed test, *** Indicate significance at $1 \%$ level in a two-tailed test. $t$ statistics are shown in parentheses.

To test hypothesis 3 , Table 10 illustrates the findings related to the integrated impact of earning management tools and an Egyptian firm's life cycle on its earnings benchmark. The adjusted $\mathrm{R}^{2}$ for each model of earnings benchmark and both earnings management tools (REM and REM) are $(2.9 \%$ and $5.1 \%)$ for J_BT, $(16.2 \%$ and $15.6 \%)$ for BT, $(0.6 \%$ and $0.9 \%)$ for J_MS, and (12.1\% and 10.8\%) for MS models respectively. These results are comparable to Hussain et al.'s (2020) findings.

In the introduction stage, Egyptian firms are more likely to 
The Relationship between Earnings Benchmarks and Earnings Management .....

Dr/ Amr Nazieh Mahmoud Ezat

engage in AEM to beat their earnings benchmarks at significant statistical level ( $\mathrm{p}<0.001)$. According to their characteristics (e.g., high spending on innovation and market activities, negative operating cash flow, low sales, and low or negative profit), such firms struggle at this stage. Therefore, they seek to beat their earnings to hide the problems that they may encounter and instead they provide good images to their investors about their future growth prospects to obtain the required finance (Hasan et al., 2017). One way to achieve this is by applying AEM and, more especially, since at the introductory stage there is a possibility of a weakness in the internal control mechanism (Krishnan et al., 2018). Accordingly, such firms are more motivated to use AEM to beat their earnings benchmarks.

In the growth stage, Egyptian firms are less likely to engage in AEM to beat their earnings benchmarks at significant statistical level ( $p<0.001)$ and are less likely to engage in REM to just beat their earnings benchmarks at significant statistical level $(\mathrm{p}<$ 0.01 ). This may be attributed to the focus that the market puts upon growth firms. Such firms are in the public eye and, therefore, this adds more pressure on them to manipulate their earnings to protect their reputations among various stakeholders. Accordingly, for such firms, the costs of performing earnings management behaviors (lost firm reputation) may exceed the rewards and benefits from applying it (beat or just beat the earnings) (Feeser and Willard; 1990; Shleifer and Vishny, 1997; 
The Relationship between Earnings Benchmarks and Earnings Management .....

Dr/ Amr Nazieh Mahmoud Ezat

Petroni et al., 2000; Marquardt and Wiedman, 2004; Dechow et al., 2010). This result is consistent with Choi et al. (2016)'s finding that growth firms are less likely to apply AEM to either meet or beat their earnings benchmarks.

In the maturity stage, Egyptian firms are less likely to engage in REM to just beat their earnings benchmarks at significant statistical level $(\mathrm{p}<0.01)$. One explanation for this result is attributed to the level of stability that such firms have at this stage. They have the power of the market and reach their maximum level of profits. Hence, they face low levels of risk and this makes them less motivated to use any of the earnings management tools to protect their positions. Such firms are already in good positions and have achieved high profits and, therefore, there is no need to beat or just beat their earnings benchmarks (Owen and Yawson, 2010; Krishnan et al., 2018).

In the decline stage, Egyptian firms are more likely to engage in AEM to beat their earnings benchmarks at significant statistical level $(\mathrm{p}<0.01)$. Such firms face severe competition that affects them and makes them more subject to financial disasters (due to low sales and poor performance). These firms need to provide any positive signs to support their continuity and to keep their debt covenants and market share (Bartov et al., 2002; Nagar and Sen, 2017). In addition, such firms have weak external monitoring systems to deter earnings management behaviors due to the problems that they encounter. This explains 
The Relationship between Earnings Benchmarks and Earnings Management .....

Dr/ Amr Nazieh Mahmoud Ezat

the possibility of such firms using AEM (Krishnan et al., 2018). Accordingly, these firms have more incentives to apply earrings management tools to beat their earnings benchmarks.

Consequently, in the Egyptian context, the interaction between earnings management and the various stages of a firm's life cycle impacts on their managers' attitude in theses stages to achieve their earnings benchmarks. Transaction cost theory confirms this result and, therefore, hypothesis 3 is accepted.

Turning to the control variables, the positive coefficient on size suggests that larger Egyptian firms are more likely to report profits (either beat or just beat their earnings. On the other hand, Egyptian firms with high levels of leverage are less likely to beat their earnings.

Table 10: Regression results of the impact of earnings management on earnings benchmarks across firm's life cycle

\begin{tabular}{|c|c|c|c|c|c|c|c|c|}
\hline & J_Bt & & BT & & J_MS & & MS & \\
\hline & \begin{tabular}{|l|} 
Model \\
$(7 a)$
\end{tabular} & Model (7b) & $\begin{array}{l}\text { Model } \\
(8 a)\end{array}$ & $\begin{array}{l}\text { Model } \\
(8 b)\end{array}$ & \begin{tabular}{|l} 
Model \\
$(9 a)$
\end{tabular} & $\begin{array}{l}\text { Model } \\
(9 b)\end{array}$ & $\begin{array}{l}\text { Model } \\
\text { (10a) }\end{array}$ & $\begin{array}{l}\text { Model } \\
(10 b)\end{array}$ \\
\hline Constant & $\begin{array}{l}\text { 0.416**** } \\
(3.019)\end{array}$ & $\begin{array}{l}\mathbf{0 . 3 4 8} * * \\
(\mathbf{2 . 5 5 5})\end{array}$ & \begin{tabular}{|l|}
$-0.432 * * *$ \\
$(-1.982)$
\end{tabular} & $\begin{array}{l}-0.292 \\
(-1.324)\end{array}$ & \begin{tabular}{|l|}
0.101 \\
$(1.313)$
\end{tabular} & \begin{tabular}{|l}
0.124 \\
$(1.597)$
\end{tabular} & $\begin{array}{l}0.765 * * * \\
(3.972)\end{array}$ & $\begin{array}{l}0.736 * * * \\
(3.763)\end{array}$ \\
\hline IN & $\begin{array}{l}-0.031 \\
(-0.783)\end{array}$ & $\begin{array}{l}-0.073 \\
(-1.490)\end{array}$ & $\begin{array}{l}-0.065 \\
(-0.844)\end{array}$ & $\begin{array}{l}-0.01 \\
(-0.121)\end{array}$ & $\begin{array}{l}0.015 \\
(0.558)\end{array}$ & $\begin{array}{l}0.018 \\
(0.634)\end{array}$ & $\begin{array}{l}0.102 \\
(1.511)\end{array}$ & $\begin{array}{l}0.074 \\
(1.025)\end{array}$ \\
\hline GW & \begin{tabular}{|l|}
-0.026 \\
$(-0.687)$
\end{tabular} & $\begin{array}{l}-0.039 \\
(-1.074)\end{array}$ & $\begin{array}{l}0.234 * * * \\
(\mathbf{3 . 0 6 0})\end{array}$ & $\begin{array}{l}0.170 * * * \\
2.669\end{array}$ & \begin{tabular}{|l|}
-0.018 \\
$(-0.662)$
\end{tabular} & \begin{tabular}{|l}
$-0.017)$ \\
$(-0.749)$
\end{tabular} & $\begin{array}{l}-0.200 * * * \\
(-2.955)\end{array}$ & $\begin{array}{l}-0.072 \\
(-1.272)\end{array}$ \\
\hline $\mathrm{MU}$ & $\begin{array}{l}-0.037 \\
(-1.396)\end{array}$ & $\begin{array}{l}-0.049 * \\
(-1.683)\end{array}$ & $\begin{array}{l}0.254 * * * \\
(5.235)\end{array}$ & $\begin{array}{l}0.241 * * * \\
(5.267)\end{array}$ & $\begin{array}{l}-0.010 \\
(-0.602)\end{array}$ & $\begin{array}{l}-0.012 \\
(-0.720)\end{array}$ & $\begin{array}{l}-0.186 * * * \\
(-4.342)\end{array}$ & $\begin{array}{l}-0.164 * * * \\
(-4.035)\end{array}$ \\
\hline $\mathrm{DC}$ & $\begin{array}{l}0.070 \\
(1.325)\end{array}$ & $\begin{array}{l}0.063 \\
(1.560)\end{array}$ & $\begin{array}{l}-0.057 \\
(-1.193)\end{array}$ & $\begin{array}{l}-.057 \\
(-1.193)\end{array}$ & \begin{tabular}{|l}
0.042 \\
$(1.057)$
\end{tabular} & \begin{tabular}{|l}
0.042 \\
$(1.057)$
\end{tabular} & $\begin{array}{l}-0.105 \\
(-0.304)\end{array}$ & $\begin{array}{l}-0.015 \\
(-0.304)\end{array}$ \\
\hline
\end{tabular}


The Relationship between Earnings Benchmarks and Earnings Management .....

Dr/ Amr Nazieh Mahmoud Ezat

\begin{tabular}{|c|c|c|c|c|c|c|c|c|}
\hline AEM & $\begin{array}{l}-0.016 \\
(-0.417)\end{array}$ & & $\begin{array}{l}0.032 \\
(0.841)\end{array}$ & & \begin{tabular}{|l|}
-0.014 \\
$(-0.355)$
\end{tabular} & & $\begin{array}{l}-0.003 \\
(-0.090)\end{array}$ & \\
\hline REM & & $\begin{array}{l}-0.009 \\
(-0.893)\end{array}$ & & $\begin{array}{l}.011 \\
(0.296)\end{array}$ & & $\begin{array}{l}-0.041 \\
(-0.607)\end{array}$ & & $\begin{array}{l}-0.051 \\
(-1.322)\end{array}$ \\
\hline $\mathrm{AEM} \times \mathrm{IN}$ & \begin{tabular}{|l|}
.017 \\
$(0.547)$
\end{tabular} & & $\begin{array}{l}0.125 * * * \\
(1.612)\end{array}$ & & $\begin{array}{l}-0.022 \\
(-1.020)\end{array}$ & & $\begin{array}{l}-0.107 \\
(-1.026)\end{array}$ & \\
\hline $\mathrm{AEM} \times \mathrm{GW}$ & $\begin{array}{l}0.040 \\
(0.673)\end{array}$ & & \begin{tabular}{|l|} 
\\
$0.194 * * *$ \\
$(-1.549)$
\end{tabular} & & $\begin{array}{l}0.014 \\
(0.329)\end{array}$ & & $\begin{array}{l}0.025 \\
(0.539)\end{array}$ & \\
\hline $\mathrm{AEM} \times \mathrm{MU}$ & $\begin{array}{l}-0.005 \\
(-0.301)\end{array}$ & & $\begin{array}{l}-0.010 \\
(-0.241)\end{array}$ & & $\begin{array}{l}-0.001 \\
(-0.096)\end{array}$ & & $\begin{array}{l}0.008 \\
(0.348)\end{array}$ & \\
\hline $\mathrm{AEM} \times \mathrm{DC}$ & $\begin{array}{l}-0.013 \\
(-0.711)\end{array}$ & & $\begin{array}{l}0.091 * * \\
(1.991)\end{array}$ & & $\begin{array}{l}-0.004 \\
(-0.328)\end{array}$ & & $\begin{array}{l}-0.038 \\
(-1.192)\end{array}$ & \\
\hline $\mathrm{REM} \times \mathrm{IN}$ & & $\begin{array}{l}-0.143 \\
(-1.292)\end{array}$ & & $\begin{array}{l}.057 \\
(0.317)\end{array}$ & & \begin{tabular}{|l|}
-0.072 \\
$(-1.146)$
\end{tabular} & & \begin{tabular}{|l}
-0.150 \\
$(-0.948)$
\end{tabular} \\
\hline $\mathrm{REM} \times \mathrm{GW}$ & & $\begin{array}{l}-0.190 * * \\
(-2.494)\end{array}$ & & $\begin{array}{l}-0.163 \\
(-1.330)\end{array}$ & & \begin{tabular}{|l|}
0.005 \\
$(0.112)$
\end{tabular} & & $\begin{array}{l}-0.052 \\
(-0.477)\end{array}$ \\
\hline $\mathrm{REM} \times \mathrm{MU}$ & & $\begin{array}{l}-0.109 * * * \\
(-2.577)\end{array}$ & & $\begin{array}{l}-0.025 \\
(-0.487)\end{array}$ & & $\begin{array}{l}-.009 \\
(-0.514)\end{array}$ & & $\begin{array}{l}-0.05 \\
(-1.088)\end{array}$ \\
\hline $\mathrm{REM} \times \mathrm{DC}$ & & $\begin{array}{l}-0.044 \\
(-1.126)\end{array}$ & & $\begin{array}{l}0.117 \\
(1.231)\end{array}$ & & $\begin{array}{l}-0.020 \\
(-1.056)\end{array}$ & & \begin{tabular}{|l}
-0.070 \\
$(-1.499)$
\end{tabular} \\
\hline Size & $\begin{array}{l}0.039 * * \\
(2.524)\end{array}$ & $\begin{array}{l}0.031 * * \\
(2.004)\end{array}$ & $\begin{array}{l}0.114 * * * \\
(4.706)\end{array}$ & $\begin{array}{l}0.113 * * * \\
4.612)\end{array}$ & $\begin{array}{l}-0.010 \\
(-1.109)\end{array}$ & $\begin{array}{l}-0.01 \\
(-1.160)\end{array}$ & $\begin{array}{l}-0.064 \\
(-2.990)\end{array}$ & $\begin{array}{l}-0.072 \\
(-0.309)\end{array}$ \\
\hline Lev & $\begin{array}{l}0.042 \\
(1.007)\end{array}$ & $\begin{array}{l}0.036 \\
(0.863)\end{array}$ & $\begin{array}{l}-0.001 * \\
(-1.673)\end{array}$ & $\begin{array}{l}-0.001 * \\
(-1.683)\end{array}$ & $\begin{array}{l}0.015 \\
(0.342)\end{array}$ & $\begin{array}{l}0.016 \\
(0.371)\end{array}$ & $\begin{array}{l}0.040 \\
(1.004)\end{array}$ & $\begin{array}{l}0.046 \\
(1.151)\end{array}$ \\
\hline$\overline{\mathrm{ROA}}$ & $\begin{array}{l}-0.005 \\
(-0.131)\end{array}$ & $\begin{array}{l}0.001 \\
(0.019)\end{array}$ & $\begin{array}{l}0.002 \\
(0.473)\end{array}$ & $\begin{array}{l}.002 \\
(0.492)\end{array}$ & $\begin{array}{l}-0.003 \\
(-0.085)\end{array}$ & $\begin{array}{l}-0.004 \\
(-0.090)\end{array}$ & $\begin{array}{l}-0.002 \\
(-0.417)\end{array}$ & $\begin{array}{l}-0.002 \\
(-0.455)\end{array}$ \\
\hline MTB & $\begin{array}{l}0.001 \\
(0.554)\end{array}$ & $\begin{array}{l}0.001 \\
(0.372)\end{array}$ & $\begin{array}{l}-0.004 \\
(-1.363)\end{array}$ & $\begin{array}{l}-0.004 \\
(-1.198)\end{array}$ & $\begin{array}{l}-0.001 \\
(-0.604)\end{array}$ & $\begin{array}{l}-0.001 \\
(-0.613)\end{array}$ & $\begin{array}{l}0.004 \\
(1.414)\end{array}$ & $\begin{array}{l}0.004 \\
(1.338)\end{array}$ \\
\hline \multicolumn{9}{|l|}{\begin{tabular}{|l} 
Other \\
statistics
\end{tabular}} \\
\hline $\begin{array}{l}\text { Industry } \\
\text { Fixed effect }\end{array}$ & Yes & Yes & Yes & Yes & Yes & Yes & Yes & Yes \\
\hline $\begin{array}{l}\text { Year Fixed } \\
\text { effect }\end{array}$ & Yes & Yes & Yes & Yes & Yes & Yes & Yes & Yes \\
\hline
\end{tabular}


The Relationship between Earnings Benchmarks and Earnings Management .....

Dr/ Amr Nazieh Mahmoud Ezat

\begin{tabular}{|l|l|l|l|l|l|l|l|l|}
\hline F-Ratio (sig.) & $1.684 * * *$ & $2.234 * * *$ & $5.463 * * *$ & $5.261 * * *$ & 0.638 & 0.690 & $4.159 * * *$ & $3.787 * * *$ \\
\hline Adj. R & 0.029 & 0.051 & 0.162 & 0.156 & 0.006 & .009 & 0.121 & 0.108 \\
\hline Max. VIF & 1.955 & 1.728 & 1.955 & 1.758 & 1.955 & 1.801 & 1.955 & 1.801 \\
\hline $\begin{array}{l}\text { Min. } \\
\text { Tolerance }\end{array}$ & 0.555 & 0.452 & 0.555 & 0.569 & 0.511 & 0.555 & 0.555 & 0.555 \\
\hline $\begin{array}{l}\text { Number of } \\
\text { observations }\end{array}$ & 648 & 648 & 648 & 648 & 648 & 648 & 648 & 648 \\
\hline
\end{tabular}

Note: The parameters in model (7a) are estimated based on the following model:

$$
\text { J_BT }=\beta 0+\beta_{1} \text { IN }+\beta_{2} \mathbf{G W}+\beta_{3} \text { MU }+\beta_{4} \text { DC }+\beta_{5} \text { AEM }+
$$

$\beta_{6}$ AEM $\times$ IN $+\beta_{7}$ AEM $\times$ GW $+\beta_{8}$ AEM $\times$ MU $+\beta_{9}$ AEM $\times$

DC $+\beta_{10}$ Size $+\beta_{11}$ Lev $+\beta_{12}$ ROA $+\beta_{13}$ MTB $+\beta_{14}$ Type $+\beta_{15}$

year $+\varepsilon$

The parameters in model ( $7 \mathrm{~b})$ are estimated based on the following model:

$\mathbf{J} \_\mathbf{B T}=\beta 0+\beta_{1} \mathrm{IN}+\beta_{\mathbf{2}} \mathbf{G W}+\boldsymbol{\beta}_{\mathbf{3}} \mathrm{MU}+\boldsymbol{\beta}_{\mathbf{4}} \mathrm{DC}+\boldsymbol{\beta}_{\mathbf{5}} \mathrm{REM}+\boldsymbol{\beta}_{\mathbf{6}}$

REM $\times$ IN $+\beta_{7}$ REM $\times$ GW $+\beta_{8}$ REM $\times$ MU $+\beta_{9}$ REM $\times$ DC +

$\beta_{10}$ Size $+\beta_{11}$ Lev $+\beta_{12}$ ROA $+\beta_{13}$ MTB $+\beta_{14}$ Type $+\beta_{15}$ year $+\varepsilon$

The parameters in model (8a) are estimated based on the following model:

$$
\mathrm{BT}=\beta 0+\beta_{1} \mathrm{IN}+\beta_{2} \mathrm{GW}+\beta_{3} \mathrm{MU}+\beta_{4} \mathrm{DC}+\beta_{5} \mathrm{AEM}+\beta_{6}
$$

$A E M \times I N+\beta_{7} A E M \times G W+\beta_{8} A E M \times M U+\beta_{9} A E M \times D C+$ $\beta_{10}$ Size $+\beta_{11}$ Lev $+\beta_{12}$ ROA $+\beta_{13}$ MTB $+\beta_{14}$ Type $+\beta_{15}$ year $+\varepsilon$ The parameters in model (8a) are estimated based on the following model: 
The Relationship between Earnings Benchmarks and Earnings Management .....

Dr/ Amr Nazieh Mahmoud Ezat

$\mathrm{BT}=\beta 0+\beta_{1} \mathrm{IN}+\beta_{2} \mathrm{GW}+\beta_{3} \mathrm{MU}+\beta_{4} \mathrm{DC}+\beta_{5} \mathrm{REM}+\beta_{6}$

REM $\times$ IN $+\beta_{7}$ REM $\times$ GW $+\beta_{8}$ REM $\times$ MU $+\beta_{9}$ REM $\times$ DC

$+\beta_{10}$ Size $+\beta_{11}$ Lev $+\beta_{12}$ ROA $+\beta_{13}$ MTB $+\beta_{14}$ Type $+\beta_{15}$ year $+\varepsilon$

The parameters in model ( $(9 \mathrm{a})$ are estimated based on the following model:

$$
\mathbf{J} \_\mathbf{M S}=\boldsymbol{\beta 0}+\boldsymbol{\beta}_{1} \mathrm{IN}+\boldsymbol{\beta}_{\mathbf{2}} \mathbf{G W}+\boldsymbol{\beta}_{3} \mathrm{MU}+\boldsymbol{\beta}_{4} \mathrm{DC}+\boldsymbol{\beta}_{5} \mathrm{AEM}+
$$

$\beta_{6} \mathrm{AEM} \times \mathrm{IN}+\beta_{7} \mathrm{AEM} \times \mathrm{GW}+\beta_{8} \mathrm{AEM} \times \mathrm{MU}+\beta_{9} \mathrm{AEM} \times \mathrm{DC}$

$+\beta_{10}$ Size $+\beta_{11}$ Lev $+\beta_{12}$ ROA $+\beta_{13}$ MTB $+\beta_{14}$ Type $+\beta_{15}$ year $+\varepsilon$

The parameters in model $(9 \mathrm{~b})$ are estimated based on the following model:

$\mathrm{J}_{-} \mathrm{MS}=\boldsymbol{\beta 0}+\boldsymbol{\beta}_{\mathbf{1}} \mathrm{IN}+\boldsymbol{\beta}_{\mathbf{2}} \mathrm{GW}+\boldsymbol{\beta}_{3} \mathrm{MU}+\boldsymbol{\beta}_{\mathbf{4}} \mathrm{DC}+\boldsymbol{\beta}_{5} \mathrm{REM}+\boldsymbol{\beta}_{6}$

REM $\times$ IN $+\beta_{7}$ REM $\times$ GW $+\beta_{8}$ REM $\times$ MU $+\beta_{9}$ REM $\times$ DC +

$\beta_{10}$ Size $+\beta_{11}$ Lev $+\beta_{12}$ ROA $+\beta_{13}$ MTB $+\beta_{14}$ Type $+\beta_{15}$ year $+\varepsilon$

The parameters in model (10a) are estimated based on the following model:

$\mathrm{MS}=\boldsymbol{\beta 0}+\boldsymbol{\beta}_{1} \mathrm{IN}+\boldsymbol{\beta}_{\mathbf{2}} \mathbf{G W}+\boldsymbol{\beta}_{3} \mathrm{MU}+\boldsymbol{\beta}_{\mathbf{4}} \mathrm{DC}+\boldsymbol{\beta}_{\mathbf{5}} \mathrm{AEM}+\boldsymbol{\beta}_{\mathbf{6}}$

$A E M \times I N+\beta_{7}$ AEM $\times$ GW $+\beta_{8}$ AEM $\times$ MU $+\beta_{9}$ AEM $\times$ DC + $\beta_{10}$ Size $+\beta_{11}$ Lev $+\beta_{12}$ ROA $+\beta_{13}$ MTB $+\beta_{14}$ Type $+\beta_{15}$ year $+\varepsilon$ The parameters in model (10b) are estimated based on the following model:

MS $=\beta 0+\beta_{1}$ IN $+\beta_{2}$ GW $+\beta_{3}$ MU $+\beta_{4}$ DC $+\beta_{5}$ REM $+\beta_{6}$ REM $\times$ IN $+\beta_{7}$ REM $\times$ GW $+\beta_{8}$ REM $\times$ MU $+\beta_{9}$ REM $\times$ DC $+\beta_{10}$ Size $+\beta_{11}$ Lev $+\beta_{12}$ ROA $+\beta_{13}$ MTB $+\beta_{14}$ Type $+\beta_{15}$ year $+\varepsilon$ 
The Relationship between Earnings Benchmarks and Earnings Management .....

Dr/ Amr Nazieh Mahmoud Ezat

\section{Variables as defined in Table 3.}

* Indicate significance at $10 \%$ level in a two-tailed test, ** Indicate significance at $5 \%$ level in a two-tailed test, *** Indicate significance at $1 \%$ level in a two-tailed test. t-statistics are shown in parentheses.

\section{Additional Analysis}

In this section, I explain some additional analysis that I employed in this study to establish the robustness to the main findings.

5.1 Examining the Impact of Earning Benchmarks on Earning Management across the Various Stages of a Firm's Life Cycle.

The investigation of the dual impacts between earnings management tools and earnings benchmarks provides more confidence of such relationship and deals, also, with the endogeneity problems. To test such an impact, I constructed the following models:

$$
\begin{aligned}
& A A E M=\beta_{0}+\beta_{1} J \_B T+\beta_{2} B T+\beta 3 J_{-} M S+\beta_{4} M S+\beta_{5} I N+\beta_{6} \\
& G W+\beta_{7} M U+\beta_{8} D C+\beta_{9} J_{-} B T \times I N+\beta_{10} J_{-} B T \times G W+\beta_{11} \\
& J \_B T \times M U+\beta_{12} J \_B T \times D C+\beta_{13} B T \times I N+\beta_{14} B T \times G W+\beta_{15} \\
& B T \times M U+\beta_{16} B T \times D C+\beta_{17} J_{-} M S \times I N+\beta_{18} J \_M S \times G W+\beta_{19} \\
& J \_M S \times M U+\beta_{20} J \_M S \times D C+\beta_{21} M S \times I N+\beta_{22} M S \times G W+\beta_{23} \\
& M S \times M U+\beta_{24} M S \times D C+\beta_{25} S i z e+\beta_{26} L e v+\beta_{27} R O A+\beta_{28} M T B
\end{aligned}
$$


The Relationship between Earnings Benchmarks and Earnings Management .....

Dr/ Amr Nazieh Mahmoud Ezat

$+\beta_{29}$ Type $+\beta_{30}$ year $+\mathbf{\varepsilon}$

$A R E M=\beta_{0}+\beta_{1} J_{-} B T+\beta_{2} B T+\beta 3 J_{-} M S+\beta_{4} M S+\beta_{5} I N+\beta_{6}$ $G W+\beta_{7} M U+\beta_{8} D C+\beta_{9} J_{-} B T \times I N+\beta_{10} J_{-} B T \times G W+\beta_{11}$ $J \_B T \times M U+\beta_{12} J \_B T \times D C+\beta_{13} B T \times I N+\beta_{14} B T \times G W+\beta_{15}$ $B T \times M U+\beta_{16} B T \times D C+\beta_{17} J \_M S \times I N+\beta_{18} J \_M S \times G W+\beta_{19}$ $J \_M S \times M U+\beta_{20} J \_M S \times D C+\beta_{21} M S \times I N+\beta_{22} M S \times G W+\beta_{23}$ $M S \times M U+\beta_{24} M S \times D C+\beta_{25}$ Size $+\beta_{26} L e v+\beta_{27} R O A+\beta_{28} M T B$ $+\beta_{29}$ Type $+\beta_{30}$ year $+\varepsilon$

The results, which were not tabulated, show that mangers of the Egyptian firms that "just beat" the earnings benchmarks are less likely to apply REM. This is compatible with the results shown in Table 10. Similarly, the managers of Egyptian firms that "just miss" and "miss" the earnings benchmarks are not motivated to perform any of the earnings management tools. Again, this is compatible with the results shown in Table 10. Turning to the Egyptian firms that "beat" the earnings benchmarks, their managers are more likely to apply both AEM and REM. This is different to the results shown in Table 10. Consequently, in the Egyptian context, there is a dual impact between earnings management and earnings benchmarks across the various stages of a firm's life cycle.

\subsection{Alternative Measure of Firm Life Cycle}

This study measures an Egyptian firm's life cycle by using a proxy, developed Dickinson (2011), to test the main hypotheses. To mitigate the concerns that the findings are sensitive to the life 
The Relationship between Earnings Benchmarks and Earnings Management .....

Dr/ Amr Nazieh Mahmoud Ezat

cycle proxy, this section employs firm age as another proxy of an Egyptian firm's life cycle (DeAngelo et al., 2010). Firm age (age) is defined as the difference between current year and the year in which the firm began to be traded on the EGX. Following Hasan et al., (2017) and Hanssen et al., (2018), this study ranks the firms into quintiles on age and uses these quintiles to classify the stages of a firm's life cycle. The findings, which are not tabulated, show few inconsistencies with the main results. As regards hypothesis 1, only the growth stage impacts on the earnings benchmark. In terms of hypothesis 2, Egyptian firms, which are in the introduction stage, are more likely to apply AEM. This supports the main findings. However, as regards REM, unlike the main results that reveal the impact of decline on REM, the managers of growth stage Egyptian firms are more motivated to apply REM. Finally, in respect of hypothesis 3, other than the exception of REM's impact on earnings benchmarks, there is a consistency with the main results across the stages of an Egyptian firm's life cycle. Generally, when this study using age as alternative proxy of the life cycle, the results corroborate the main results reported in Section 4.

\subsection{Using Absolute Figure of AEM and REM}

Some previous studies used the absolute values of AEM and REM (Lazzem and Jilani, 2018; Pappas et al., 2019; Hussain et al., 2020). Therefore, this study runs the models by using the absolute values of AEM and REM to check the robustness of the 
The Relationship between Earnings Benchmarks and Earnings Management .....

Dr/ Amr Nazieh Mahmoud Ezat

main results. In respect of findings for hypothesis 1 that are not tabulated, these are consistent with the results related to AEM. However, when using the absolute value of REM, the introduction and growth stages are found to have an impact on REM and on the decline stage. Turning to hypothesis 3, other than the impact of mature- firms that apply AEM on "beat" benchmarks, the obtained results are compatible with the main results. Consequently, the use of the absolute figure of AEM and REM supports the main findings reported in Section 4.

\subsection{Discussion of the Results according to the Sectors of the Listed Egyptian Firms}

Having regard to the results that were not tabulated, the highest sector that just beat the earnings benchmark is travel $(31.37 \%)$ in the decline stage. The highest sector that beat the earnings benchmark is real estate $(15.84 \%)$ in the decline stage. The highest sector that just missed the earnings benchmark is travel $(28.57 \%)$ in the decline stage. The highest sector that missed the earnings benchmark is travel (14.75\%) in the maturity stage. Further, in this respect, the highest sector that performs REM is Introduction (-0.462) in the Introduction stage. Finally, the highest sector that performs AEM is personal (0.814) in the introduction stage.

\section{Conclusion}

This study extends the previous studies on firm life cycle by investigating the relationship between earnings management and 
The Relationship between Earnings Benchmarks and Earnings Management .....

Dr/ Amr Nazieh Mahmoud Ezat

earnings benchmarks across the sample of non-financial Egyptian firms' life cycles listed in financial the period from 2016 to 2019. I employed ten models of panel date regression analysis to test the formulated hypotheses.

The descriptive findings illustrate that most of the sampled Egyptian firms are in the decline stage and the minority are in the growth stage. Further, more generally, most of the sampled Egyptian firms report profits across the various stages of their life cycles and, especially, in the mature stage. The sampled Egyptian firms that "beat" and "just beat" the earnings' benchmarks are higher than those that either "miss" or "just miss" the benchmarks. More specifically, the sampled Egyptian firms in the decline stage are more likely to just beat the benchmark of earnings than the other stages. However, the firms at the maturity stage have the highest mean in terms of beating the earnings. In addition, the sampled Egyptian firms are relatively more interested in applying AEM than REM for all stages of their life cycles. More specifically, when compared to those firms at the other stages, the sampled Egyptian firms in the introduction stage are more likely to apply earnings management tools. The sampled Egyptian firms, which seek to beat their earnings benchmarks, are more motivated to use earnings management tools.

The empirical findings indicates that each stage of the sampled Egyptian firm's life cycle impacts on the earnings attributes. 
The Relationship between Earnings Benchmarks and Earnings Management .....

Dr/ Amr Nazieh Mahmoud Ezat

Therefore, hypothesis 1 is accepted. The sampled Egyptian firms in both the growth and maturity stages are more likely to beat the earnings' benchmark while those firms in the introduction and decline stages are more likely to miss their earnings benchmarks. Further, other than the exception of the maturity stage, Egyptian firms in each stage of the life cycle are engaged in earnings management. Therefore, hypothesis 2 is accepted. Introductory stage Egyptian firms are more likely to use AEM than REM while such firms at the decline stage are more likely to use REM than AEM. However, Growth stage Egyptian firms are less likely to use earnings management tools, namely AEM. Therefore, hypothesis 3 is accepted. In addition, the findings indicate that earnings management tools impact on earning benchmarks across the various stages of the sampled Egyptian firm life cycles. Both AEM and REM have significant associations with only "beat" and "just beat" benchmarks across the life cycle stages. In the introduction and decline (growth)stages, the sampled Egyptian firms are more (less) likely to use AEM to beat the earnings benchmarks. However, in the growth and mature stages, the sampled Egyptian firms have fewer incentives to use REM to "just beat" the earnings benchmarks.

These findings provide interesting implications. For investors, the findings provide empirical evidence of the relationship between earnings management and earnings management across the various stages of a firm's life cycle. Investors should consider 
The Relationship between Earnings Benchmarks and Earnings Management .....

Dr/ Amr Nazieh Mahmoud Ezat

this relationship when evaluating each Egyptian firm's performance. The information related to the stages of firm life cycle can help investors. They should pay more attention when investing in the early and decline stage firms and should carefully evaluate the behaviours of their earnings benchmarks. For financial analysts, the findings indicate the importance of determining the stages of an Egyptian firm's life cycle and, more especially when determining these firms' desires to achieve their earnings targets. Financial analysts determining the various stages of an Egyptian firm's life cycle can help them to predict these managers' behaviours on earnings and, hence, provide accurate decisions. For creditors, the findings reveal that the various aspects of the Egyptian firm's life cycle influence its managers' behaviours in relation to earnings management and earnings benchmarks. Therefore, creditors should be more cautious when extending credit and they should carefully consider the current stage of the Egyptian firm's life cycle. For managers, the findings identify the different characteristics of each stage of an Egyptian firm's life cycle. These support managers when taking rational decisions across these stages and should help them to use the firm's resources wisely. For academic research, the findings extend the previous studies in the field of firm life cycle, earnings management and earnings benchmarks. Also, they provide empirical evidence of the importance of determining the stages of a firm's life cycle when 
The Relationship between Earnings Benchmarks and Earnings Management .....

Dr/ Amr Nazieh Mahmoud Ezat

examining the association between earnings management and earnings benchmarks. Bearing in mind the lack of similar studies, these findings should encourage researchers to explore such a relationship in different contexts in the Middle East region.

However, this study suffered from some limitations. First, this study concentrated mainly on the non-financial listed Egyptian firms. Consequently, I recommend that future research studies extend the samples to include the financial listed firms to investigate the various characteristics of their firm life cycle stages in the Middle East region. Second, this study examined two tools of earnings management; these were, namely, AEM and REM. I recommend, also, that future research studies investigate another earnings management tool such as classification shifting in different contexts. Third, this study identified different earnings bins around zero earning as a proxy for earnings benchmarks. I recommend, also, that future research studies explore another proxy for earning benchmarks such as analysts' forecasts or previous year's earnings to investigate its association with earnings management across the stages of a firm's life cycle. 
The Relationship between Earnings Benchmarks and Earnings Management .....

Dr/ Amr Nazieh Mahmoud Ezat

\section{References}

Abdullah, A.A. and Mohd-Saleh, N. (2014), "Impact of firms' life-cycle on conservatism: the Malaysian evidence", Procedia-Social and Behavioral Sciences, Vol.145, pp.18-28.

Agarwal, R. and Audretsch, D.B. (2001), "Does entry size matter? The impact of the life cycle and technology on firm survival", The Journal of Industrial Economics, Vol. 49 No.1, pp.21-43.

Akbar, A., Akbar, M., Tang, W. and Qureshi, M.A. (2019), "Is bankruptcy risk tied to corporate life-cycle? Evidence from

Pakistan", Sustainability, Vol. 11 No.3, p.678.

Alzoubi, T. (2019), "Firms' Life Cycle Stage And Cash Holding Decisions", Academy of Accounting and Financial Studies Journal, Vol. 23 No.1, pp.1-8.

Anandarajan, A., Chiang, S. and Lee, P. (2010), "R\&D tax credit and operating performance: Implications for managers", Management Decision, Vol. 48 No. 8, pp.1198-1211.

Anderson, C.R. and Zeithaml, C.P. (1984), "Stage of the product life cycle, business strategy, and business performance", Academy of Management journal, Vol. 27 No.1, pp.5-24.

Anthony, J.H. and Ramesh, K. (1992), “Association between accounting performance measures and stock prices: A test of the life cycle hypothesis", Journal of Accounting and economics, Vol. 15 No.2-3, pp.203-227.

Ayers, B.C., Jiang, J. and Yeung, P.E. (2006), "Discretionary accruals and earnings management: An analysis of pseudo earnings targets", The Accounting Review, Vol. 81 No.3, pp.617-652.

Bakarich, K.M., Hossain, M. and Weintrop, J. (2019), "Different time, different tone: Company life cycle", Journal of Contemporary Accounting \& Economics, Vol. 15 No.1, pp.69-86. 
The Relationship between Earnings Benchmarks and Earnings Management .....

Dr/ Amr Nazieh Mahmoud Ezat

Barclay, M.J. and Smith, C.W. (2005), “The capital structure puzzle: The evidence revisited", Journal of applied corporate finance, Vol. 17 No.1, pp.8-17.

Bartov, E. and Cohen, D.A. (2009), "The "numbers game" in the pre-and post-Sarbanes-Oxley eras", Journal of Accounting, Auditing \& Finance, Vol. 24 No.4, pp.505-534.

Bartov, E., Givoly, D. and Hayn, C. (2002), "The rewards to meeting or beating earnings expectations", Journal of accounting and economics, Vol. 33 No.2, pp.173-204.

Barua, A., Lin, S. and Sbaraglia, A.M. (2010), "Earnings management using discontinued operations", The Accounting Review, Vol. 85 No.5, pp.1485-1509.

Bauman, M.P., Braswell, M. and Shaw, K.W. (2005), “The numbers game: How do managers compensated with stock options meet analysts' earnings forecasts?", Research in Accounting Regulation, Vol. 18, pp.3-28.

Black, E.L. (1998), "Life-cycle impacts on the incremental value-relevance of earnings and cash flow measures", Journal of Financial Statement Analysis, Vol. 4 No.1 , pp.40-57.

Black, E. (2003), "Usefulness of financial statement components in valuation: an examination of start-up and growth firms", Venture Capital: An International Journal of Entrepreneurial Finance, Vol. 5 No.1, pp.47-69.

Brown, L.D. and Caylor, M.L. (2005), “A temporal analysis of quarterly earnings thresholds: Propensities and valuation consequences", The Accounting Review, Vol. 80 No. 2, pp.423-440.

Bulan, L. and Yan, Z. (2009), "The pecking order of financing in the firm's life cycle", Banking and Finance Letters, Vol. 1 No.3, pp.129-40.

Burgstahler, D. and Dichev, I. (1997), "Earnings management to avoid 
The Relationship between Earnings Benchmarks and Earnings Management .....

Dr/ Amr Nazieh Mahmoud Ezat

earnings decreases and losses", Journal of accounting and economics, Vol. 24 No.1, pp.99-126.

Can, G. (2020), "Do Life-Cycles Affect Financial Reporting Quality?

Evidence from Emerging Market", Cogent Business \&

Management, Vol. 7 No.1, p.1854147.

Chang, H.S. (2015), "Firm life cycle and detection of accrual-based earnings manipulation", Unpublished thesis, University of Illinois at UrbanaChampaign.

Charitou, A., Lambertides, N. and Trigeorgis, L. (2011), "Distress risk, growth and earnings quality", Abacus, Vol. 47 No.2, pp.158-181.

Chen, T. (2016), "Internal control, life cycle and earnings quality-An empirical analysis from Chinese market", Open Journal of Business and Management, Vol. 4 No.2, pp.301-311.

Chen, X., and Huang, D. (2008), “ The corporate life cycle, accrual characteristics and accounting conservatism", China Accounting and Finance Review, Vol. 10 No.1, pp.34-68.

Chen, X., Yang, W. and Huang, D. (2010), "Corporate life cycle and the accrual model: An empirical study based on Chinese listed companies", Frontiers of Business Research in China, Vol. 4 No.4, pp.580-607.

Cheng, Q. and Warfield, T.D. (2005), "Equity incentives and earnings management", The accounting review, Vol. 80 No.2, pp.441-476

Chevis, G., Das, S. and Sivaramakrishnan, S. (2007), "Does it Pay to Consistently Meet Analysts' Earnings Expectations?", Working Paper, Baylor University,Waco, TX, Available at SSRN 982841.

Chiang, S., Lee, P. and Anandarajan, A. (2013), "Corporate governance and innovative success: An examination of the moderating influence of a firm's life cycle stage”, Innovation, Vol. 15 No.4, pp.500-514.

Choi, J., Choi, W. and Lee, E. (2016), "Corporate life cycle and earnings 
The Relationship between Earnings Benchmarks and Earnings Management .....

Dr/ Amr Nazieh Mahmoud Ezat

benchmarks", Australian Accounting Review, Vol. 26 No.4, pp.415428.

Chung, Y., Pan, L., Huang, S.Y., and Chen, K.C. (2015), "Do firms change earnings management behavior after receiving financial forecast warnings?", Global Finance Journal, Vol. 27, pp.1-17.

Cohen, D.A. and Zarowin, P. (2010), “Accrual-based and real earnings management activities around seasoned equity offerings", Journal of accounting and Economics, Vol. 50 No.1, pp.2-19.

Collins, D.W . and Kothari, S.P. (1989), “An analysis of intertemporal and cross-sectional determinants of earnings response coefficients", Journal of accounting and economics, Vol. 11 No.2-3, pp.143-181.

Cornell, B. and Shapiro, A.C. (1987), "Corporate stakeholders and corporate finance", Financial management, Vol. 16 No.1, pp.5-14.

DeAngelo, H., DeAngelo, L. and Stulz, R.M. (2006), "Dividend policy and the earned/contributed capital mix: a test of the life-cycle theory", Journal of Financial economics, Vol. 81 No.2, pp.227-254.

DeAngelo, H., DeAngelo, L. and Stulz, R.M. (2010), "Seasoned equity offerings, market timing, and the corporate lifecycle", Journal of financial economics, Vol. 95 No.3, pp.275-295.

Da Silva Roma, C.M., Louzada, L.C., da Silva Roma, P.M., Goto, H. and Souma, W. (2020), "Earnings management, policy uncertainty and firm life cycle stages: evidence from publicly traded companies in the USA and Brazil", Journal of Financial Economic Policy, Vol. 13 No.3, pp. 371-390.

Dechow, P., Ge, W. and Schrand, C. (2010), "Understanding earnings quality: A review of the proxies, their determinants and their consequences", Journal of accounting and economics, Vol. 50 No.23, pp.344-401. 
The Relationship between Earnings Benchmarks and Earnings Management .....

Dr/ Amr Nazieh Mahmoud Ezat

Dechow, P.M. and Skinner, D.J. (2000), "Earnings management:

Reconciling the views of accounting academics, practitioners, and regulators", Accounting horizons, Vol. 14 No.2, pp.235-250.

DeFond, M.L. and Jiambalvo, J. (1994), "Debt covenant violation and manipulation of accruals", Journal of accounting and economics, Vol. 17 No.1-2, pp.145-176.

Degeorge, F., Patel, J. and Zeckhauser, R. (1999), "Earnings management to exceed thresholds", The Journal of Business, Vol. 72 No.1, pp.1-33.

Dickinson, V. (2011), "Cash flow patterns as a proxy for firm life cycle”, The Accounting Review, Vol. 86 No.6, pp.1969-1994.

Dickinson, V., Kassa, H. and Schaberl, P.D. (2018), "What information matters to investors at different stages of a firm's life cycle?", Advances in accounting, Vol. 42, pp.22-33.

Dodge, H.R. and Robbins, J.E. (1992), "An empirical investigation of the organizational life cycle", Journal of small business management, Vol. 30 No.1, p.27.

Drake, K.D. (2012), "Does firm life cycle explain the relation between book-tax differences and earnings persistence?", Unpublished thesis, Arizona State University.

Drobetz, W., Halling, M. and Schröder, H. (2015), "Corporate life-cycle dynamics of cash holdings", Swedish House of Finance Research Paper, Working paper, available at SSRN 2578315.

Elsayed, K. and Paton, D. (2009), "The impact of financial performance on environmental policy: does firm life cycle matter?", Business Strategy and the Environment, Vol. 18 No.6, pp.397-413.

Ertimur, Y., Livnat, J. and Martikainen, M. (2003), "Differential market reactions to revenue and expense surprises", Review of Accounting Studies, Vol. 8 No.2, pp.185-211.

Fan, Y., Barua, A., Cready, W.M. and Thomas, W.B. (2010), "Managing 
The Relationship between Earnings Benchmarks and Earnings Management .....

Dr/ Amr Nazieh Mahmoud Ezat

earnings using classification shifting: Evidence from quarterly special items", The Accounting Review, Vol. 85 No.4, pp.1303-1323. Faff, R., Kwok, W.C., Podolski, E.J. and Wong, G. (2016), "Do corporate policies follow a life-cycle?”, Journal of Banking \& Finance, Vol. 69, pp.95-107.

Feeser, H.R. and Willard, G.E. (1990), "Founding strategy and performance: A comparison of high and low growth high tech firms", Strategic management journal, Vol. 11 No.2, pp.87-98.

Fields, T., Lyz, T. and Vincent, L. (2001), "Empirical research on accounting choice", Journal of Accounting and Economics, Vol.31 No.1-3, pp.255-308.

Gore, P., Pope, P.F. and Singh, A.K. (2007), "Earnings management and the distribution of earnings relative to targets: UK evidence", Accounting and business research, Vol. 37 No.2, pp.123149.

Graham, J.R., Harvey, C.R. and Rajgopal, S. (2005), "The economic implications of corporate financial reporting", Journal of accounting and economics, Vol. 40 No. 1-3, pp.3-73.

Güleç, Ö.F. and Karacaer, S. (2018), "Corporate Life Cycle Theory and Accounting Performance: Borsa Istanbul Case", The Journal of Accounting and Finance, Vol. 78, pp. 265-279.

Habib, A. (2010), "Value relevance of alternative accounting performance measures: Australian evidence", Accounting Research Journal, Vol. 23 No.2, pp.190-212.

Habib, A. and Hansen, J.C. (2008), “Target shooting: Review of earnings management around earnings benchmarks", Journal of Accounting Literature, Vol. 27, pp.25-70.

Habib, A. and Hasan, M.M. (2017), "Firm life cycle, corporate risk-taking and investor sentiment", Accounting \& Finance, Vol. 57 No.2, 
The Relationship between Earnings Benchmarks and Earnings Management .....

Dr/ Amr Nazieh Mahmoud Ezat

pp.465-497.

Habib, A. and Hasan, M.M. (2019), "Corporate life cycle research in accounting, finance and corporate governance: A survey, and directions for future research", International Review of Financial Analysis, Vol. 61, pp.188-201.

Hansen, J.C., Hong, K.P. and Park, S.H. (2018), “Accounting conservatism: A life cycle perspective", Advances in Accounting, Vol. 40, pp.7688.

Hasan, M.M. and Habib, A. (2017), "Corporate life cycle, organizational financial resources and corporate social responsibility", Journal of Contemporary Accounting \& Economics, Vol. 13 No.1, pp.20-36.

Hasan, M.M., Al-Hadi, A., Taylor, G. and Richardson, G. (2017), "Does a firm's life cycle explain its propensity to engage in corporate tax avoidance?", European Accounting Review, Vol. 26 No.3, pp.469501.

Hastuti, T.D., Ghozali, I. and Yuyetta, E.N.A. (2017), “The effect of company life cycles on the accruals earnings management with internal control system as moderating variable", Polish journal of management studies, Vol. 15 No.1, pp.66-75.

Healy, P. M. and Wahlen, J. M. (1999), “A Review of the Earnings Management Literature and its Implications for Standard Setting", Accounting Horizons, Vol. 13 No.4, pp.365-383.

Hossain, M., Hossain, M., Mitra, S. and Salama, F. (2019), "Narrative disclosures, firm life cycle, and audit fees", International Journal of Auditing, Vol. 23 No.3, pp.403-423.

Houmes, R.E. and Skantz, T.R. (2010), "Highly valued equity and discretionary accruals", Journal of Business Finance \& Accounting, Vol. 37 No.1-2, pp.60-92.

Hribar, P. and Yehuda, N. (2015), “The mispricing of cash flows and 
The Relationship between Earnings Benchmarks and Earnings Management .....

Dr/ Amr Nazieh Mahmoud Ezat

accruals at different life-cycle stages", Contemporary Accounting Research, Vol. 32 No.23, pp.1053-1072.

Hsu, F.J. and Chen, S.H. (2018). "Corporate Social Responsibility and Firm Life-cycles", Working Paper, National Taichung University of Science and Technology, Department of Insurance and Finance, Kaohsiung.

Hussain, A., Akbar, M., Kaleem Khan, M., Akbar, A., Panait, M. and Catalin Voica, M. (2020), "When Does Earnings Management Matter? Evidence across the Corporate Life Cycle for Non-Financial Chinese Listed Companies", Journal of Risk and Financial Management, Vol. 13 No.12, p.313.

Jaafar, H. and Halim, H.A. (2016), "Refining the firm life cycle classification method: A firm value perspective", Journal of Economics, Business and Management, Vol. 4 No.2, pp.112-119.

Jenkins, D.S., Kane, G.D. and Velury, U. (2004), "The impact of the corporate life-cycle on the value-relevance of disaggregated earnings components", Review of Accounting and Finance, Vol. 3 No.4, pp.520.

Jensen, M.C. (2005), “Agency costs of overvalued equity”, Financial management, Vol. 34 No.1, pp.5-19.

Jiang, J. (2008), "Beating earnings benchmarks and the cost of debt", The Accounting Review, Vol. 83 No.2s, pp.377-416.

Kahneman, D. and Tversky, A. (1979), "Prospect theory: An analysis of decision under risk", Econometrica, Vol. 47 No.2, pp. 263-292.

Kale, D. and Almeida, J.E.F. (2019), “The quality of accruals across life cycle stages", in Southwestern Finance Association 2019 Annual Meeting (SWFA), 13-16 March, 2019, Houston, TX

Kallunki, J.P. and Silvola, H. (2008), "The effect of organizational life cycle stage on the use of activity-based costing", Management accounting 
The Relationship between Earnings Benchmarks and Earnings Management .....

Dr/ Amr Nazieh Mahmoud Ezat

research, Vol. 19 No.1, pp.62-79.

Kasznik, R. and McNichols, M.F. (2002), "Does meeting earnings expectations matter? Evidence from analyst forecast revisions and share prices", Journal of Accounting research, Vol. 40 No.3, pp.727759.

Koh, K., Matsumoto, D.A. and Rajgopal, S. (2008) "Meeting or beating analyst expectations in the post-scandals world: Changes in stock market rewards and managerial actions", Contemporary Accounting Research, Vol. 25 No.4, pp.1067-1098.

Koonce, L. and Lipe, M.G. (2010), "Earnings trend and performance relative to benchmarks: How consistency influences their joint use", Journal of Accounting Research, Vol. 48 No.4, pp.859-884.

Koonce, L. and Mercer, M. (2005), "Using psychology theories in archival financial accounting research", Journal of Accounting Literature, Vol. 24 No.1, pp. 175-214.

Kothari, S.P. (2001), "Capital markets research in accounting", Journal of accounting and economics, Vol. 31 No.1-3, pp.105-231.

Kothari, S.P., Leone, A.J. and Wasley, C.E. (2005), "Performance matched discretionary accrual measures", Journal of accounting and economics, Vol. 39 No.1, pp.163-197.

Krishnan, G.V., Myllymäki, E.R. and Nagar, N. (2018), "Does financial reporting quality vary across firm life cycle?", working paper, SSRN 3233512.

Kuo, J., Ning, L., and Song, X., (2014), “The Real and Accrual-based Earnings Management Behaviors: Evidence from the Split Share Structure Reform in China", The International Journal of Accounting, Vol. 49 No.3, pp.101-136.

Lazzem, S. and Jilani, F. (2018), "The impact of leverage on accrual-based earnings management: The case of listed French firms", Research in 
The Relationship between Earnings Benchmarks and Earnings Management .....

Dr/ Amr Nazieh Mahmoud Ezat

International Business and Finance, Vol. 44 , pp.350-358.

Lee, W.J. and Choi, S.U. (2018), "Effects of corporate life cycle on corporate social responsibility: Evidence from

Korea", Sustainability, Vol. 10 No.10, p.3794.

Lee, W.J., Li, L.Y. and Yue, H. (2006), "Performance, growth and earnings management", Review of Accounting Studies, Vol. 11 No.2-3, pp.305-334.

Li, Y. and Zhang, X.T. (2018), "How does firm life cycle affect board structure? evidence from China's listed privately owned enterprises", Management and Organization Review, Vol. 14 No.2, pp.305-341.

Liu, M.M. (2006), “Accruals and managerial operating decisions over the firm life cycle (Doctoral dissertation", Unpublished thesis, Massachusetts Institute of Technology.

Madhogarhia, P., Sutton, N.K. and Kohers, T. (2009), "Earnings management practices among growth and value firms. Applied Financial Economics", Vol. 19 No.22, pp.1767-1778.

Marquardt, C.A. and Wiedman, C.I. (2004), "How are earnings managed? An examination of specific accruals", Contemporary Accounting Research, Vol. 21 No.2, pp.461-491.

Matsunaga, S.R. and Park, C.W. (2001), "The effect of missing a quarterly earnings benchmark on the CEO's annual bonus", The Accounting Review, Vol. 76 No.3, pp.313-332.

Mata, J. and Freitas, E. (2012), "Foreignness and exit over the life cycle of firms”, Journal of International Business Studies, Vol. 43 No.7, pp.615-630.

McVay, S.E. (2006), "Earnings management using classification shifting:

An examination of core earnings and special items", The Accounting Review, Vol. 81 No.3, pp.501-531. 
The Relationship between Earnings Benchmarks and Earnings Management .....

Dr/ Amr Nazieh Mahmoud Ezat

McVay, S., Nagar, V. and Tang, V.W. (2006), “Trading incentives to meet the analyst forecast", Review of Accounting Studies, Vol. 11 No.4, pp.575-598.

Michalkova, L. (2021), "Earnings Quality and Accruals over Company' S Life Cycle”, SHS Web of Conferences, Vol. 92, pp.1-10.

Miller, D. and Friesen, P.H. (1984), "A longitudinal study of the corporate life cycle”, Management science, Vol. 30 No.10, pp.1161-1183.

Nabar, S., and X. Song. (2017), "Growth firms' real earnings management practices", Journal of Forensic \& Investigative Accounting, Vol. 9 No.1,pp. 606-620

Nagar, N. and Radhakrishnan, S. (2017), "Firm life cycle and real-activity based earnings management", Working paper Indian Indian Institute Management and University of Texas, Available at SSRN 2701680.

Nagar, N. and Sen, K. (2017), "Classification shifting: impact of firm life cycle", Journal of Financial Reporting and Accounting, Vol. 15 No.2, pp.180-197.

Osma, B.G. and Young, S. (2009), "R\&D expenditure and earnings targets", European Accounting Review, Vol. 18 No.1, pp.7-32.

Owen, S. and Yawson, A. (2010), "Corporate life cycle and M\&A activity”, Journal of banking \& finance, Vol. 34 No.2, pp.427-440.

Pachariyanon, P. (2014), "The relationship between company life-cycle and the choice of earnings management", Unpublished thesis, Minato, Tokyo, Jepan.

Pappas, K., Walsh, E. and Xu, A.L. (2019), "Real earnings management and Loan Contract terms", The British Accounting Review, Vol. 51 No.4, pp.373-401.

Petroni, K.R., Ryan, S.G. and Wahlen, J.M. (2000), “Discretionary and nondiscretionary revisions of loss reserves by property-casualty insurers: Differential implications for future profitability, risk and market 
The Relationship between Earnings Benchmarks and Earnings Management .....

Dr/ Amr Nazieh Mahmoud Ezat

value", Review of Accounting Studies, Vol. 5 No.2, pp.95-125.

Phillips, J., Pincus, M. and Rego, S.O. (2003), "Earnings management: New evidence based on deferred tax expense", The Accounting Review, Vol. 78 No.2, pp.491-521.

Roychowdhury, S. (2006), "Earnings management through real activities manipulation", Journal of accounting and economics, Vol. 42 No.3, pp.335-370.

Selling, T.I. and Stickney, C.P. (1989), “The effects of business environment and strategy on a firm's rate of return on assets", Financial Analysts Journal, Vol. 45 No. 1, pp.43-52.

Shiue, M.J., Chang, Y.S. and Jhu, L.Y. (2012), "Real Earnings Management and Future Performance: Testing the Life-Cycle Hypothesis", Working paper, Deloitte Taiwan.

Shleifer, A. and Vishny, R.W. (1997), "A survey of corporate governance”, The journal of finance, Vol. 52 No.2, pp.737-783.

Siriviriyakul, S. (2014), "Re-examining real earnings management to avoid losses", Doctoral dissertation, UC Berkeley.

Skinner, D.J. and Sloan, R.G. (2002), "Earnings surprises, growth expectations, and stock returns or don't let an earnings torpedo sink your portfolio", Review of accounting studies, Vol. 7 No.2, pp.289312.

Stam, E. and Verbeeten, F. (2017), "Tax compliance over the firm life course”, International Small Business Journal, Vol. 35 No.1, pp.99115.

Suberi, A.Z.M., Hsu, G. and Wyatt, A. (2012), "The relation between firm growth and accounting quality: A test of the life cycle hypothesis", Working paper, Australia: University of Queensland.

Sweeney, A.P. (1994), "Debt-covenant violations and managers' accounting responses", Journal of accounting and Economics, Vol. 17 No.3, 
The Relationship between Earnings Benchmarks and Earnings Management .....

Dr/ Amr Nazieh Mahmoud Ezat

pp.281-308.

Vorst, P. and Yohn, T.L. (2018), "Life cycle models and forecasting growth and profitability”, The Accounting Review, Vol. 93 No.6, pp.357381.

Warusawitharana, M. (2018), "Profitability and the Lifecycle of Firms", The BE Journal of Macroeconomics, Vol. 18 No.2, pp. 1-45.

Wernerfelt, B. (1984), “A resource-based view of the firm”, Strategic management journal, Vol. 5 No.2, pp.171-180.

Zadband, Vahid Khosravi, and Hamed Omrani (2014), “The Effect of Corporate Life Cycle on Financial Reporting Quality Companies Listed in Tehran Stock Exchange", International Journal of Management \& Information Technology, Vol. 9 No.2 , pp. 15641571

Zalata, A.M. and Roberts, C. (2017), "Managing earnings using classification shifting: UK evidence", Journal of International Accounting, Auditing and Taxation, Vol.29, pp.52-65.

Zamri, N., Rahman, R.A. and Isa, N.S.M. (2013), "The impact of leverage on real earnings management", Procedia Economics and Finance, Vol. 7 , pp.86-95.

Zamrudah, R. and Salman, K.R. (2013), "Earnings management prediction (a study of company's life cycle", The Indonesian Accounting Review, Vol. 3 No.2, pp.107-120.

Zhang, Y. (2018), “Two Essays on String of Earnings Benchmarks", Unpublished thesis, Muma College of Business, University of South Florida.

Zhipeng, Y. and Zhao, Y. (2009), “A New Methodology of Measuring Firm Life-Cycle Stages", International Journal of Economic Perspectives, Vol. 4 No. 4, pp.579-587. 